\title{
Male Lower Urinary Tract Dysfunction: An Underrepresented Endpoint in Toxicology Research
}

\author{
Nelson T. Peterson ${ }^{1}$ and Chad M. Vezina ${ }^{1,2, *}$ \\ 1 Molecular and Environmental Toxicology Graduate Program, University of Wisconsin-Madison, \\ Madison, WI 53706, USA; ntpeterson3@wisc.edu \\ 2 Department of Comparative Biosciences, University of Wisconsin-Madison, Madison, WI 53706, USA \\ * Correspondence: chad.vezina@wisc.edu
}

check for updates

Citation: Peterson, N.T.; Vezina, C.M. Male Lower Urinary Tract

Dysfunction: An Underrepresented Endpoint in Toxicology Research.

Toxics 2022, 10, 89. https://doi.org/ $10.3390 /$ toxics 10020089

Academic Editor: Soisungwan Satarug

Received: 4 January 2022

Accepted: 11 February 2022

Published: 16 February 2022

Publisher's Note: MDPI stays neutral with regard to jurisdictional claims in published maps and institutional affiliations.

Copyright: (C) 2022 by the authors. Licensee MDPI, Basel, Switzerland. This article is an open access article distributed under the terms and conditions of the Creative Commons Attribution (CC BY) license (https:// creativecommons.org/licenses/by/ $4.0 /)$.

\begin{abstract}
Lower urinary tract dysfunction (LUTD) is nearly ubiquitous in men of advancing age and exerts substantial physical, mental, social, and financial costs to society. While a large body of research is focused on the molecular, genetic, and epigenetic underpinnings of the disease, little research has been dedicated to the influence of environmental chemicals on disease initiation, progression, or severity. Despite a few recent studies indicating a potential developmental origin of male LUTD linked to chemical exposures in the womb, it remains a grossly understudied endpoint in toxicology research. Therefore, we direct this review to toxicologists who are considering male LUTD as a new aspect of chemical toxicity studies. We focus on the LUTD disease process in men, as well as in the male mouse as a leading research model. To introduce the disease process, we describe the physiology of the male lower urinary tract and the cellular composition of lower urinary tract tissues. We discuss known and suspected mechanisms of male LUTD and examples of environmental chemicals acting through these mechanisms to contribute to LUTD. We also describe mouse models of LUTD and endpoints to diagnose, characterize, and quantify LUTD in men and mice.
\end{abstract}

Keywords: lower urinary tract dysfunction; lower urinary tract symptoms; $\mathrm{BPH}$; prostate

\section{Introduction}

LUTD is a deviation from normal urinary voiding. While LUTD occurs in males and females, disease mechanisms differ between sexes. The prostate plays a considerable role in male LUTD, the focus of this review. For such a pervasive disease, male LUTD has suffered from a surprising lack of research attention. Part of the problem is the disease's complexity, driven by a constellation of underlying factors across multiple organs that are incompletely understood. Another problem is that the historical research record for LUTD is muddled by vast and inconsistent nomenclature used to describe the disease, decentralizing the resource of primary peer-reviewed literature. Several vocabulary terms are used to describe histological, anatomical, physiological, and clinical pathologies in the lower urinary tract. The following terms are sometimes conflated or interchanged with LUTD, and often used inappropriately: benign prostatic hyperplasia $(\mathrm{BPH})$, benign prostatic enlargement $(\mathrm{BPE})$, bladder outlet obstruction (BOO), partial bladder outlet obstruction (pBOO), lower urinary tract symptoms (LUTS), and others. These terms are defined in Table 1.

Male LUTD can be confirmed by specialized urodynamic studies at the urology clinic (diagnostic and experimental approaches used to identify LUTD mechanisms in mice and humans are described in Table 2). However, male LUTD is most often identified in the primary care clinic based on patient reported symptoms. LUTS can include but are not limited to weak stream, incomplete bladder emptying and more frequent voiding, especially at night. Male LUTD frequently begins in the fifth decade of life or later and is a progressive disease that can result in a loss of bladder function, bladder and kidney stones, acute urinary retention, and renal injury/failure [1-7]. LUTD disrupts sleep and 
has been linked to depression, decreased workplace productivity, and a reduced quality of life [8-12]. If not successfully managed, LUTD can be fatal.

Table 1. Definitions of terms used to describe anatomical and physiological disorders of the male lower urinary tract.

\begin{tabular}{|c|c|c|}
\hline Acronym & Term & Definition \\
\hline $\mathrm{BPE}$ & $\begin{array}{l}\text { Benign Prostatic } \\
\text { Enlargement }\end{array}$ & $\begin{array}{l}\text { Non-malignant enlargement of the prostate, } \\
\text { defined by imaging or digital rectal exam, and } \\
\text { usually caused by BPH. }\end{array}$ \\
\hline $\mathrm{BPH}$ & $\begin{array}{l}\text { Benign Prostatic } \\
\text { Hyperplasia }\end{array}$ & $\begin{array}{l}\text { Histologically defined benign growth within the } \\
\text { prostate. In humans, the growth pattern is } \\
\text { nodular and can be primarily epithelial, stromal } \\
\text { or mixed patterns of hyperplasia. BPH is often } \\
\text { responsible for BPE. }\end{array}$ \\
\hline $\mathrm{BPO}$ & $\begin{array}{l}\text { Benign Prostatic } \\
\text { Obstruction }\end{array}$ & BOO secondary to BPE. \\
\hline \multirow[t]{2}{*}{$\mathrm{BOO}$} & $\begin{array}{l}\text { Bladder Outlet } \\
\text { Obstruction }\end{array}$ & $\begin{array}{l}\text { Blockage of urine passage from an obstruction at } \\
\text { the base of the bladder or bladder neck. }\end{array}$ \\
\hline & Clinical Prostatitis & $\begin{array}{l}\text { A spectrum of conditions characterized by } \\
\text { differing degrees of inflammation, bacterial and } \\
\text { abacterial, of the prostate, genitourinary tract or } \\
\text { pelvis and may not include the prostate. }\end{array}$ \\
\hline $\mathrm{DO}$ & Detrusor Overactivity & $\begin{array}{c}\text { A urodynamic observation characterized by } \\
\text { involuntary detrusor contractions during the } \\
\text { filling phase that may be spontaneous } \\
\text { or provoked. }\end{array}$ \\
\hline \multirow[t]{2}{*}{ DSD } & $\begin{array}{l}\text { Detrsor Spincter } \\
\text { Dyssynergia }\end{array}$ & $\begin{array}{c}\text { A disorder where the detrusor muscle contracts } \\
\text { while the urethral and/or periurethral sphincter } \\
\text { is involuntarily contracted and closed, resulting } \\
\text { in bladder outlet obstruction. }\end{array}$ \\
\hline & Histological Prostatitis & $\begin{array}{l}\text { Prostate inflammation detected in a } \\
\text { biopsy specimen. }\end{array}$ \\
\hline LUTD & $\begin{array}{c}\text { Lower Urinary Tract } \\
\text { Dysfunction }\end{array}$ & $\begin{array}{l}\text { A detrimental deviation from normal voiding } \\
\text { function. Examples include decreased flow rate, } \\
\text { increased voiding frequency, increased or } \\
\text { decreased sensation associated with filling, an } \\
\text { inability to completely void urine, and an } \\
\text { inability to store urine until voluntary release. }\end{array}$ \\
\hline LUTS & $\begin{array}{l}\text { Lower Urinary Tract } \\
\text { Symptoms }\end{array}$ & $\begin{array}{l}\text { Patient described symptoms, scored using the } \\
\text { international prostate symptom score, the } \\
\text { American Urological Association Symptom } \\
\text { index, or other indices that may (or may not) } \\
\text { include bother. }\end{array}$ \\
\hline $\mathrm{OAB}$ & Overactive Bladder & $\begin{array}{l}\text { Urgency to urinate with or without urge } \\
\text { incontinence, and usually associated with } \\
\text { increased voiding frequency. }\end{array}$ \\
\hline OVD & $\begin{array}{l}\text { Obstruction Voiding } \\
\text { Disorder }\end{array}$ & $\begin{array}{l}\text { Lower urinary tract dysfunction deriving from } \\
\text { an obstruction in the lower urinary tract. }\end{array}$ \\
\hline \multirow[t]{3}{*}{ pBOO } & $\begin{array}{l}\text { Partial Bladder Outlet } \\
\text { Obstruction }\end{array}$ & $\begin{array}{c}\text { Partial blockage of urine passage from an } \\
\text { obstruction at the base of the bladder or } \\
\text { bladder neck. }\end{array}$ \\
\hline & Prostatitism & Male LUTD deriving from a prostatic mechanism \\
\hline & Prostatomegaly & $\begin{array}{c}\text { Prostate enlargement from malignant or } \\
\text { non-malignant mechanisms. }\end{array}$ \\
\hline
\end{tabular}


Table 2. Strengths and limitations of methods to evaluate lower urinary tract dysfunction in men and male mice.

\begin{tabular}{|c|c|c|}
\hline Method in Men & Method in Male Mice & Method Description \\
\hline $\begin{array}{l}\text { Cell and tissue-based } \\
\text { calcium flux assays }\end{array}$ & $\begin{array}{l}\text { Cell and tissue-based } \\
\text { calcium flux assays }\end{array}$ & $\begin{array}{l}\text { Calcium indicator dyes or } \\
\text { genetically encoded calcium } \\
\text { sensors are used to measure } \\
\text { intracellular calcium concentrations } \\
\text { in response to pharmacological } \\
\text { agents and electrical field stimuli. }\end{array}$ \\
\hline
\end{tabular}
Cystometry Cystometry

Cystoscopy Not available

Histology and immunohistochemistry

Histology and immunohistochemistry
A catheter is placed in the bladder and the bladder is filled with water or saline while measuring pressures associated with bladder filling and emptying. The catheter can also be used to collect post-void residual urine in the bladder.
A cystoscope is inserted into the urethra to visualize the lower urinary tract.
Strengths and Limitations

This method has been applied in vitro with human and mouse tissues and cells, and in vivo with mice, penetration can be limited for calcium indicator dyes and genetically encoded sensors are generally limited to mouse tissues.

Effective at measuring bladder pressure, but catheter is placed

retropublicly in mice and transurethrally in humans which can contribute to intraspecies variability. Baseline pattern can vary by strain in mice.

Effective in identifying prostatic enlargement, urethral and bladder inflammation, and some urological cancers, but this method is not available for mice.

Effective for assessing anatomical and cellular changes in lower urinary

Tissues sections are evaluated for $\mathrm{BPH}$, inflammation and collagen accumulation (definitive diagnosis of $\mathrm{BPH}$, histological prostatitis, fibrosis) and can be used to assess LUTD mechanisms. tract tissues and definitive diagnosis for some urological diseases but is invasive and therefore control tissues are difficult to obtain for healthy men for experimental comparisons; definitive identification of cell types requires complex multiplex protocols.

Bladder, prostate, or urethral tissue is mounted in saline bath,

Isometric contractility Isometric Contractility pharmacological agents or electrical field stimuli are applied and force displacement is measured.

Quantitative and can reveal specific receptor mediated mechanisms of muscle function but is invasive and destructive to tissue (cannot be easily multiplexed with other methods.

Quantifies bladder wall thickness, detrusor and bladder volume,

Magnetic resonance imaging

Magnetic resonance imaging

Symptom score

Not applicable bladder neck angle, urethral length and diameter and prostate volume.
Can identify mechanisms of LUTD

(bladder decompensation, BPE), but time consuming and expensive.
Standardized surveys such as the American Urological Association Symptom Index, the International Prostate Symptom Score, LURN, the National Institutes of Health-chronic prostatitis symptom index (NIH-CPSI) and others are used to quantify urinary symptoms and quality of life

Quantifies bladder volume and wall thickness, urethral lumen diameter and in mice, velocity of urine as it passes through the urethra.
Rapid, inexpensive and can be given repeatedly to monitor disease progression or responsiveness to therapy; limited to humans and not applicable for mice.

Fast but high-resolution imaging (for mice) requires expensive equipment.
Ultrasound

Ultrasound 
Table 2. Cont.

\begin{tabular}{|c|c|c|c|}
\hline Method in Men & Method in Male Mice & Method Description & Strengths and Limitations \\
\hline Uroflowmetry & Uroflowmetry & $\begin{array}{l}\text { Performed by measuring voided } \\
\text { urine flow and volume. }\end{array}$ & $\begin{array}{c}\text { Non-invasive, but requires } \\
\text { specialized equipment, and operator } \\
\text { experience and cannot distinguish } \\
\text { between anatomical (bladder, } \\
\text { prostate, or urethra) mechanisms } \\
\text { of LUTD. }\end{array}$ \\
\hline Voiding diary & Void spot assay & $\begin{array}{l}\text { Men use a journal to record urinary } \\
\text { void frequency, timing, and use a } \\
\text { capture container to record volume; } \\
\text { for mice, a filter paper is placed at } \\
\text { the bottom of the cage and later } \\
\text { illuminated to quantify void spot } \\
\text { number, size, and pattern. }\end{array}$ & $\begin{array}{l}\text { Inexpensive, noninvasive, but can } \\
\text { vary by day and individual and } \\
\text { cannot distinguish mechanism } \\
\text { (bladder, urethra, prostate) of } \\
\text { voiding dysfunction. }\end{array}$ \\
\hline
\end{tabular}

LUTD is extremely common. A 2008 study estimated that 1.9 billion people, representing $45 \%$ of the population, are affected by LUTD [9]. The economic burden of LUTD is staggering. The disease affects more than half of men over 50 years of age in the Western world, resulting in $\$ 4$ billion for the pharmacological treatment and $\$ 2$ billion for the surgical treatment of LUTD and associated prostatic problems [13-15]. The most common therapies for male LUTD are directed to block alpha adrenoreceptor function (alpha blockers) and dihydrotestosterone synthesis (steroid 5 alpha reductase inhibitors), factors which contribute to prostatic smooth muscle contraction and prostatic enlargement, respectively. Unfortunately, these therapies are incompletely effective. Their magnitude of effect is marginal, not all patients respond, and existing therapies are only moderately protective against disease progression [16-18]. It is becoming clear that male LUTD derives from many different mechanisms, not all of which are addressed by current therapies. Factors responsible for severe drug-refractory disease are not understood. Recent studies reveal potential roles for environmental chemical exposures, during the fetal period when the lower urinary tract is developing [19-21] and during other stages, in driving LUTD susceptibility and progression, opening an entirely new line of toxicology research towards understanding environmental factors that contribute to LUTD processes.

This review is intended as a resource for toxicologists and other discipline specialists who are considering entry into the urologic disease research space and wishing to examine LUTD as a toxicology research endpoint. We describe the anatomy, cellular composition, and physiology of male lower urinary tract organs including the bladder, urethra, and prostate. We describe known and emerging disease mechanisms. We also highlight the limited examples of how environmental chemicals influence male LUTD and list opportunities for future research.

\section{Overview of Male Lower Urinary Tract Anatomy and Physiology}

Several benign diseases of the lower urinary tract are accompanied by a change in distribution, type, or state of cells that comprise lower urinary tract tissues [22-24]. Therefore, we describe the cellular anatomy of the male lower urinary tract to give toxicologists an appreciation of the normal cellular organization and changes which occur in response to chemical insults and disease The male lower urinary tract consists of the bladder, prostate, and urethra (Figure 1). Urine flows from the kidney to the bladder via the ureter and passes through the prostatic urethra and prostate before continuing through the penile urethra and exiting the body as voided urine (Figure 1). 


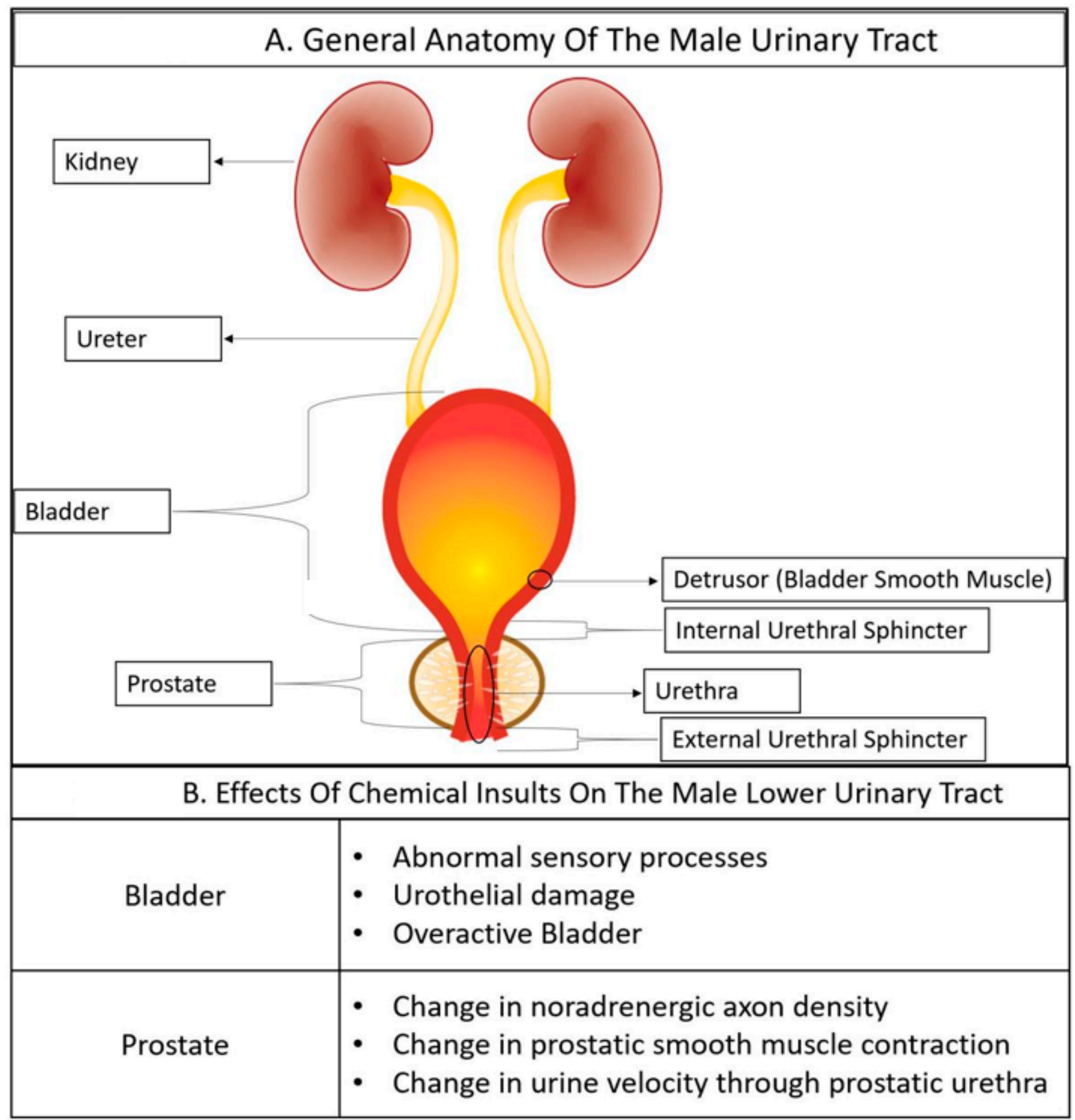

Figure 1. General anatomy of the male urinary tract and effects of chemical insults on the male lower urinary tract. (A) A general depiction of the male lower urinary tract. (B) Known effects of environmental chemicals on the lower urinary tract of either the man or male mouse.

\subsection{The Bladder}

The bladder's primary functions are to store and expel urine. The bladder wall consists of three tissue layers: a specialized epithelium known as the urothelium, the lamina propria, and the bladder smooth muscle (detrusor) [25,26].

The mature urothelium is comprised of basal, intermediate, and superficial cells [27]. Bladder epithelial cell differentiation begins early in fetal development (weeks 7-8 in humans), and the trajectory of urothelial cell differentiation during development and regeneration is susceptible to epigenetic modification [28] revealing a potential mechanism of toxicity for epigenetic modifying chemicals. The mature urothelium must achieve 
three unique functions. The first is to maintain distensibility to accommodate bladder filling and emptying. Bladder volume increases significantly during the storage cycle, a process which would normally challenge the integrity of an epithelial lining [29]. Bladder distensibility is achieved by urothelial cell junction rearrangements and cell sliding during bladder filling [29].

The second role of the urothelium is to protect sub-urothelial tissue from toxins, microorganisms, and urine solutes [27,30]. Barrier function is facilitated by secreted uroplakins [31]. Uroplakins are transmembrane proteins which assemble into a crystalline structure and are interrupted by hinge regions to allow bladder distension [32]. Uroplakins assemble to form uroplaques, rigid bio-membrane structures which cover $90 \%$ of bladder lumen [32]. Uroplaques are integral to the integrity, flexibility, and solubility of the urothelium [33]. The control of urothelial cell division is integral to maintaining functional uroplaques and restoring them after bladder damage. Although the urothelial cell turnover is normally slow with a labeling index of $1 \%$ in mice, the urothelium is reconstituted quickly after injury through the progenitor activities of basal and intermediate cells [32-36]. The epithelium of the urothelium can be completely repaired in 4 weeks in guinea pigs and 6 weeks in men [36]. Some mechanisms by which the bladder restores barrier function are surprising. For example, we found that under certain circumstances when widespread urothelial cell death depletes the bladder of its own progenitors, it can recruit non-resident, non-bladder (Wolffian duct) epithelial progenitors, drive their differentiation into uroplakin secreting superficial cells and restore barrier function [37]. Barrier function is crucial because sub-epithelial bladder cells are severely compromised by urine exposure. The experimental use of cyclophosphamide, an antineoplastic used therapeutically for Hodgkin's lymphoma, multiple myeloma, and other cancers, has widened the understanding of barrier function and consequences of barrier function loss. Cyclophosphamide is bio-transformed into acrolein, which accumulates in the urine and drives urothelial cell death, resulting in hemorrhagic cystitis and changes in physiology [38-40]. Environmental chemicals with urothelial cell toxicity are expected to drive bladder inflammation and dysfunction like that of cyclophosphamide.

The third role of the urothelium is that of a sensor. In combination with nerve terminals within the bladder, the urothelium detects and responds to mechanical and chemical stimuli to alter detrusor contractility and moderate bladder afferent nerve activity [41,42]. Factors released by urothelial cells include acetylcholine, adenosine triphosphate (ATP), nerve growth factor, nitric oxide (NO), prostaglandins, and others [41,43].

The lamina propria contains a fibroelastic connective tissue with intervening afferent and efferent nerve fibers, a vast vascular network and dispersed fibroblasts, a loose smooth muscle layer (the muscularis mucosa), and myofibroblasts [26,44]. The elastic fibers within the lamina propria allow the bladder to recover its original shape after voiding [45].

The detrusor is the major smooth muscle component of the bladder [46]. The detrusor is organized as a circular muscle inner layer sandwiched between longitudinal muscle outer layers [46]. Muscle bundles are surrounded by collagen [46-48]. Detrusor contraction is predominantly controlled by cholinergic neurons $[49,50]$, but can also be induced by purinergic neurons and relatively rare sympathetic neurons $[49,50]$.

The normal voiding cycle is divided into filling and voiding phases [51]. Urine expands the bladder during the filling phase, while bladder pressure remains lower than urethral pressure $[50,51]$. There is still uncertainty about how the bladder relays the perception of fullness to the brain. One possibility is that mechanoreceptors and mechanosensitive ion channels within the bladder transmit information about fullness to afferent neurons [52-56]. There is also evidence that urothelial cells, stretched during bladder filling, release ATP to activate purinergic receptors on bladder afferents and relay bladder fullness to the brain [57-59]. Another possibility is that the perception of fullness is not driven by a slow increase in bladder pressure (intravesicular pressure), but rather by an increasing rate of spontaneous transient contractions, also called micromotions, which exist throughout the filling phase. Micromotions drive the major portion of afferent outflow to the central nervous system 
during bladder filling, acting in part through a mechanism involving calcium-activated potassium (SK type) channels [60].

In 1925, F.J.F. Barrington identified a brain stem region which controls micturition, including sensation of bladder fullness and the contractions leading to urination [61]. Studies using retrograde and anterograde neuronal labeling pinpointed the location of this micturition center in the pontine tegmentum [62-67]. This site of micturition control is referred to as Barrington's nucleus, the pontine micturition center, and the M-region [62]. Afferent and efferent urinary voiding pathways are integrated in Barrington's nucleus. During the storage phase, glutamatergic neurons in the periaqueductal gray and hypothalamus relay information about bladder fullness and bladder volume threshold for voiding to Barrington's nucleus [68,69]. During the voiding phase, corticotropin releasing hormone-positive and estrogen receptor 1-positive neurons within Barrington's nucleus activate efferent pathways to drive detrusor contraction [62,70,71]. Additional neurons in Barrington's nucleus send inhibitory signals to the external urethral sphincter, driving its relaxation and allowing urine to flow unimpeded from the bladder into the urethra [71-73]. Though there is widespread evidence that environmental contaminants can disrupt connectivity, complexity, arborization, and signaling of neurons within the peripheral and central nervous system, whether environmental chemicals impact bladder ascending and descending neural pathways is rarely examined [74-80].

There is limited evidence that environmental chemical exposures can disrupt bladder neural circuitry as it is established during the fetal and neonatal periods, raising concerns about a developmental basis of bladder health and disease. A recent study tested the impact of exposure to a polychlorinated biphenyl (PCB) mixture on bladder structure and function [19]. The PCB mixture used in this study mimics the most encountered congeners in women who are at risk for having a child with a neurodevelopmental disorder [81, 82]. PCBs were delivered orally to nulliparous female mice (75\% C57BL/6J / 25\% SVJ129) starting two weeks before mating, through pregnancy and lactation, and continuing in offspring before their bladders were analyzed at postnatal days 28-31. The PCB mixture increased densities of sub-urothelial beta-3 tubulin (general neural fiber marker) fibers and calcitonin gene-related peptide positive (peptidergic fiber marker) fibers in male mice but not female mice, and these changes were accompanied by an increase in male bladder volume [19], suggesting they were sufficient to drive a change in bladder function.

\subsection{The Urethra}

The human male urethra is divided into two parts, consisting of five segments: the anterior urethra (fossa, penile, and bulbar segments) and the posterior urethra (membranous and prostatic segments) [83]. The rodent male urethra is divided into two parts-penile and pelvic [84]. The human and rodent urethra are populated by epithelial cells, smooth and striated muscle cells, blood vessels, and sensory and motor neurons [85]. While the cellular components of the anterior/penile urethra have not been extensively characterized, single cell ribonucleic acid (RNA) sequencing approaches have been used to determine the cellular components of the prostatic urethra $[24,86,87]$. Urethral epithelium consists of club cells, hillock cells, basal epithelial cells, and neuroendocrine cells [86]. Urethral club and hillock cells were recently identified, but their functional characterization is incomplete and represents a future research opportunity. Lung club cells, which are transcriptionally like those in the urethra, act as progenitors and mediate anti-inflammatory and antioxidant processes [88-90]. Lung hillock cells, which are transcriptionally like those in the urethra, serve as progenitors, and participate in barrier function and immunomodulation [91,92].

\subsection{The Urethral Sphincter}

The urethral sphincter serves as a valve to regulate urine flow between the bladder and urethra [93]. During the bladder storage phase, urethral pressure exceeds bladder pressure to maintain continence [50]. During the voiding phase, the urethral sphincter falls open, urethral pressure decreases while bladder pressure increases, the urethra distends and 
urine flows through the prostatic urethra and penile urethra to become voided urine [50]. The urethral sphincter is divided into two parts: the external sphincter and the internal urethral sphincter $[93,94]$. The external sphincter consists of striated muscle circumscribing the urethra and is under voluntary control $[93,95]$. The internal urethral sphincter is indistinct from the rest of the lower urinary tract smooth muscle (bladder smooth muscle is continuous with urethral and prostatic smooth muscle), but is physiologically defined by its autonomic regulation, connected via a reflex arc to the bladder $[95,96]$. Urethral smooth muscle is organized as a thin longitudinal superficial layer, a dense circular layer, and a thin longitudinal deep layer [94].

\subsection{The Prostate}

The prostate synthesizes a portion of the ejaculate [97]. Prostatic smooth muscle contracts during ejaculation to propel prostatic fluid into the urethra [98]. The prostatic urethra also distends to accommodate urine during voiding. Benign prostatic disease changes the prostate's histology and cellular composition and can prevent prostatic urethral distention during voiding, causing BOO, a common etiology for LUTD (defined in Table 1).

The human prostate is a spherical gland encapsulated by a fibromuscular sheath known as the prostatic capsule $[24,96,99]$. The base of the prostate is adjacent to the bladder and the prostatic urethra courses through its center [100]. The prostatic ductal network is like that of a branched tree: the main ducts drain directly into the urethra and divide into primary, secondary, and tertiary branches as they extend towards acini concentrated in the gland's periphery [101]. The human prostate is organized into zones, differing in cellular composition and responsiveness to disease, and includes the transition zone (most susceptible to histological BPH, defined in Table 1) [24,102], the central zone and the peripheral zone (most susceptible to prostate cancer) [100,102]. The rodent prostate, often used as a disease model for humans, is anatomically distinct from the human prostate in that it is not spherical, but instead divided into four bilaterally symmetrical lobes: the anterior, dorsal, lateral, and ventral prostate [102]. While spontaneous cancer is not observed in the mouse prostate, a variety of genetically engineered mouse models are susceptible to prostate cancer and disease incidence differs by lobe [103]. The mouse prostate gland develops BPH spontaneously with age, but lesions are diffuse, like those that contribute to clinical disease in the dog, and unlike nodular BPH in the humans [104,105]. The rodent prostate ductal network is organized as a branched tree, like that of the human prostate, but ducts are surrounded by a looser stroma than in human prostate and the rodent gland is encapsulated in a thin adventitia instead of the thick capsule that surrounds the human prostate.

Human prostatic epithelium is made up of luminal, basal cells; neuroendocrine, club and hillock cells are also present, but are rare in prostate compared to urethral epithelium $[22,86,106]$. Human prostate stroma consists of three smooth muscle cell types (peri-prostatic, vascular smooth muscle and pericyte), two fibroblast cell types (peri-epithelial and interstitial), leukocytes, endothelial cells, and sensory and autonomic nerve fibers [86]. Mouse prostate stroma contains three fibroblast cell subtypes distributed in distinct proximal-distal and lobe-specific patterns and smooth muscle $[24,106]$. The transcriptomes of mouse prostatic and urethral fibroblasts are like human interstitial fibroblasts [24]. However, mouse urethral and ductal fibroblasts evoke Wingless relatedintegration site (Wnt) and Transforming growth factor beta (TGF $\beta$ ) signaling pathways that are less abundant in human prostate fibroblasts [24]. Human peri-epithelial fibroblasts instead express Wnt inhibitors that could buffer Wnt ligands produced by other stromal or epithelial cells [24]. Human prostatic fibroblasts are organized in layers that center around epithelial structures, while mouse prostatic fibroblasts are not layered and differ by lobe [24]. Human and mouse prostate fibroblasts are most abundant in the proximal regions of prostatic ducts and least abundant in acini in the distal regions [24,107].

The recent observation, derived from single cell RNA-sequencing data, that human and mouse prostate cellular landscapes are similar, is also supported by previous microarray 
data [108]. Similarly, mouse prostate organogenesis is like that of the human prostate [109]. These data support the use of mice as a relevant model species for studying cellular and molecular mechanisms of benign prostatic disease. The key to understanding the differences in prostate architecture and benign prostate hyperplasia manifestation between these species may lie in the function of the specialized prostate epithelial and stromal cells of these species [109].

Prostate disease can be detected by changes in the spatial distribution and frequency of prostate cells [24]. Prostate cell immunophenotyping has proven difficult, as disease processes frequently lead to changes in cell state and cell type that cannot be easily distinguished by simple immunohistochemical staining protocols. New and validated RNASequencing approaches, as well as cell sorting protocols deriving from them, have recently been described [86] and will be essential for elucidating prostate cell functions in future studies.

\section{LUTD Mechanisms}

\subsection{Benign Prostatic Diseases}

A variety of benign prostatic conditions contribute to male LUTD, many of which are believed to cause LUTD by driving BOO (defined in Table 1). The impacts of BOO extend beyond the prostate and into the bladder. A prolonged intravesicular pressure increase and bladder contraction against resistance reprograms the bladder in a process known as bladder compensation: the detrusor becomes thicker [110], it undergoes functional changes in ion channel physiology [111] and efferent signaling is reprogrammed [112]. If $\mathrm{BOO}$ is not effectively addressed, the bladder decompensates, much like a heart undergoing hypertrophic cardiomyopathy: the detrusor thins, is replaced by fibrotic tissue, and becomes incapable of mounting an effective contraction to fully evacuate urine from the bladder. There is evidence in rabbits that bladder decompensation is at least partially reversed by relief of bladder outlet obstruction [113]. Recovery from BOO likely depends on the severity of bladder decompensation at the time of surgery [113-115]. Thus, BOO must be effectively addressed before it permanently impairs bladder function.

$\mathrm{BPH}$ is a leading cause of LUTD in men of advancing age. Human BPH is defined by prostate histology, specifically the presence of stromal, epithelial, or mixed nodules in the central and transition zones (Table 1) [22,116-120]. Small hyperplastic nodules can form as early as the 3rd decade of life and increase in frequency and volume with advancing age [121]. BPH mechanisms are not fully understood, but it has been hypothesized that BPH arises from a reawakening of embryonic signaling pathways [121] or disrupted homeostatic regulation of cell growth and death programs [116-120].

Aging-related changes in circulating testosterone and 17-beta-estradiol concentrations are another mechanism linked to male LUTD. Serum and prostate tissue concentrations of testosterone and 17-beta-estradiol change with age in men $[122,123]$ and the changes are associated temporally and mechanistically with male LUTD [124-126]. Pharmacological alterations in testosterone and 17-beta-estradiol are a proven cause of LUTD in non-human male primates, canines, rats, and mice [124,127-133]. In mice, slow-release implants of testosterone and estradiol drive an increase in voiding frequency, a reduction in voided volume, an increase in collagen deposition, and a change in velocity of urine flow through the prostatic urethra [124]. The mechanism by which changes in circulating testosterone and 17-beta-estradiol drive voiding dysfunction are not clear but may include direct actions on the bladder [134,135], changes in prostatic desmin and smooth muscle actin content or function [136-139].

The fact that LUTD arises from natural changes in circulating sex hormone concentration raises questions about impacts of endocrine disrupting chemicals on male voiding function, and this area of toxicology research is in its infancy. For example, subcutaneous implants of the estrogenic chemical bisphenol A (BPA, $25 \mathrm{mg}$ ), combined with testosterone $(2.5 \mathrm{mg}$ ) and given to C57BL/ $6 \mathrm{~N}$ adult (6-8 weeks old) male mice, increase bladder mass and volume, increase voiding frequency, and reduce the volume of voided urine, suggestive 
of BOO [140]. BPA may act more broadly in the lower urinary tract, affecting the bladder as well as the prostate. Delivery of BPA $(0.05-0.5 \mathrm{mg} / \mathrm{kg} /$ day $)$ to Pietrain $\times$ Duroc mixedbreed juvenile female pigs increases the number and thickness of vasoactive intestinal polypeptide (VIP) expressing neurons in the bladder wall [141], raising questions about the influence of BPA, and the larger class of environmental estrogens to which it belongs, on detrusor recovery after contraction.

Prostate inflammation, also called prostatitis (defined in Table 1), is extremely common and has been closely associated with LUTD. Approximately 50\% of prostate biopsy, surgical or autopsy specimens harbor evidence of histological inflammation, most typically characterized as chronic (lymphocytic) inflammation [142]. The incidence of prostate histological inflammation is even higher (75\%) in men with LUTD [143]. The presence of prostate inflammation in a biopsy specimen correlates with risk of symptomatic progression, urinary retention, and need for surgery [142,144-146]. A significant proportion of men with histologically defined prostate inflammation will develop urinary dysfunction [147]. Two placebo-controlled drug trials, Reduction by Dutasteride of Prostate Cancer Events (REDUCE) and Medical Therapy of Prostatic Symptoms (MTOPS), correlate histological prostate inflammation in human male prostate with increased prostate volume [144]. MTOPS study outcomes reveal that men with histological inflammation are more likely to progress to advanced LUTD, including acute urinary retention [144]. A separate study found that men with prostatitis were 2.4 times more likely to develop BPH and the presence of histological prostate inflammation in baseline biopsies was associated with $70 \%$ increased odds of requiring later treatment for LUTD [146]. Despite clear evidence that some environmental chemicals can drive inflammation and modulate autoimmunity, there is little information about environmental impacts on prostate inflammation and this represents a future opportunity that can be examined using immunohistochemical and physiological methods in Table 2.

There is a distinction between histological and clinical prostatitis: histological prostatitis is identified in histological tissue sections, while clinical prostatitis is diagnosed by physical examination, urinalysis, imaging, cystoscopy, or patient questionnaire (for example, The National Institute of Health Chronic Prostatitis Symptom Index (NIH-CPSI)) [148]. Clinical prostatitis accounts for a significant proportion of outpatient visits [149]. Clinical prostatitis includes acute and chronic bacterial prostatitis, nonbacterial prostatitis, and asymptomatic prostatitis [148].

Prostate fibrosis is a recently identified mechanism of male LUTD. Fibrosis is an abnormal, detrimental version of the wound-healing process and is characterized by collagen deposition and tissue stiffening [150]. Macoska et al. [151] were the first to report fibrosis in the human prostate and link collagen accumulation to tissue stiffness and LUTS severity. Subsequent reports linked prostate fibrosis to histological inflammation, LUTS, and resistance to a combination therapy of alpha blockers and 5 alpha reductase inhibitors $[150,152]$. Prostatic fibrosis is an evolutionarily conserved LUTD process, supported by the fact that collagens also accumulate within the prostates of aging intact dogs and mice [104,153]. Though triggers for prostate fibrosis are not fully known, and whether environmental contaminants drive prostate fibrosis has not been studied, prostatic fibrosis results from prostate inflammation secondary to $E$. coli infection or obesity in mice $[154,155]$.

Prostatic smooth muscle dysfunction is the target of the most prescribed drug class for male LUTD, the alpha blockers, and can be studied experimentally using calcium flux assays and isometric contractility assays described in Table 2. A study by Baumgarten et al. [156] was the first to identify noradrenergic axons in the human prostate, a surprising discovery considering that autonomic outflow to the bladder is mediated instead by cholinergic axons. Receptor binding studies and isometric contractility assays showed that noradrenergic receptors in prostatic smooth muscle mediate prostate tissue contractility $[157,158]$. The outcomes of these studies ushered the hypothesis that prostatic smooth muscle hyperactivity impairs urine flow through the prostatic urethra to cause BOO in some men. While this hypothesis was the basis for developing alpha blockers for male LUTD, little research 
has been directed at identifying mechanisms of prostatic smooth muscle dysfunction, most notably dysfunction mediated by environmental chemicals. This area remains ripe for scientific exploration. Prostatic smooth muscle contraction is controlled by autonomic neurons and aging is one factor that may contribute to changes in prostatic innervation [124,159]. There is emerging evidence that environmental chemicals can also change prostatic innervation to cause prostatic smooth muscle dysfunction, specifically by acting during the fetal and neonatal periods when prostate autonomic innervation is established. For example, we recently showed in C57BL/6J mice that gestational exposure to the widespread environmental contaminant TCDD (a single $1 \mu \mathrm{g} / \mathrm{kg}$ oral maternal dose on the 13th day of gestation) increases noradrenergic fiber density (nerve terminals) in the prostate of male mouse fetuses without changing the density of cholinergic or peptidergic fibers [160]. TCDD-induced prostatic noradrenergic hyperinnervation persists into adulthood and is coupled to hyperactivity of prostatic smooth muscle and abnormal urinary function in mice, including increased urinary frequency [160]. These findings are important because they support the concept that prostate neuroanatomical development is malleable, at least in mice, and that intrauterine chemical exposures can permanently reprogram prostate neuromuscular function to cause male LUTD in adulthood. In contrast, exposure to TCDD and other aryl hydrocarbon receptor agonists during adulthood appear to protect against $\mathrm{BPH}$ in men [161,162]. Differing consequences of aryl hydrocarbon receptor activation in the fetal period, versus adulthood, highlight the need to control for age in studies that examine potential impacts of environmental chemicals on urinary function and LUTD.

\subsection{Bladder Mechanisms of Male LUTD}

A variety of bladder conditions can lead to urinary dysfunction. This section describes the most common causes of male LUTD.

Overactive bladder is characterized by involuntary detrusor contraction. Consistent changes in animal models of overactive bladder include patchy denervation of the bladder, enlarged sensory neurons, hypertrophic dorsal root ganglia, and an enhanced spinal micturition reflex [163]. Overactive bladder is often characterized by sensory dysfunction [163]. There is a role for muscarinic M2 receptors in the severity of urinary urgency [163]. Some individuals with overactive bladder have a thicker bladder wall, suggesting overactive bladder may derive from BOO in some men [163,164].

The etiology of overactive bladder is multifactorial, deriving from three major mechanisms: myogenic factors, urotheliogenic factors, and neurogenic factors [41]. Myogenic factors contributing to overactive bladder include spontaneous detrusor contractions in response to bladder distension, ischemia, and changes in smooth muscle properties over time [41]. Neurogenic factors may include abnormal sensory processes, abnormal afferent excitability, or in some cases, damage, or abnormalities in central processing [41]. Dimethylaminopropionitrile, used in the manufacture of polyurethane, is an inhalation hazard that acts through a neurogenic mechanism to cause overactive bladder [165]. Methyl mercury also causes overactive bladder through what appears to be a neurogenic mechanism $[166,167]$. Damage to the urothelium can also cause overactive bladder, as rupture of urothelial cells releases factors that can drive detrusor contractility and micturition [41]. Biphenyl, used as a resin, a heat transfer medium, and an anti-fungal, is an example of an environmental chemical that causes urothelial cell damage and death [168].

Underactive bladder, also known as detrusor underactivity, is defined by detrusor contraction of inadequate strength, and results in prolonged or incomplete bladder emptying [169]. Patients with underactive bladder have a diminished sense of bladder fullness and are unable to mount forceful bladder contractions [170]. Underactive bladder can occur after episodic overactive bladder, reminiscent of bladder decompensation after BOO. In fact, there is a documented relationship between LUTD, underactive bladder, and fibrosis of the bladder [171]. The interstitial cells of Cajal, a specialized cell population with smooth muscle pacemaking activity, have been implicated in underactive bladder. The frequency of interstitial cells of Cajal is reduced in mice with underactive bladder and is associated with 
reduced frequency and amplitude of detrusor contraction [172]. Rats driven by bladder outlet obstruction to develop underactive bladder are deficient in stem cell factor, a ligand for the receptor C-kit which controls proliferation and function of interstitial cells of Cajal, and an increase in stem cell factor restores detrusor contractility [172].

\subsection{Urethral Mechanisms of Male LUTD}

Detrusor sphincter dyssynergia is characterized by simultaneous contraction of the detrusor and urinary sphincter, thereby impairing urine outflow from the bladder [173]. Detrusor sphincter dyssynergia manifests in three distinct phenotypes: (Type 1) increased sphincter activity during detrusor contraction which then ceases, resulting in delayed urination, (Type 2) intermittent clonic contractions during voiding, resulting in intermittent stream, (Type 3) continuous sphincter activity during detrusor contraction, resulting in impaired voiding [174]. Detrusor sphincter dyssynergia is common in men with spinal cord injuries or multiple sclerosis and has the capability to drive bladder decompensation, elevate pressure in the ureter and pelvis, and cause hydronephrosis, renal scarring and terminal kidney failure $[173,174]$.

Neurological disease commonly manifests in bladder dysfunction [175]. Autonomic nervous system lesions (stroke, tumor, traumatic spinal cord injury, myelopathies due to cervico-arthrosis spina bifida), disseminated lesions (Parkinson's disease, brain trauma, multiple sclerosis, meningo-encephalitis,) and peripheral neuropathies (diabetes mellitius) have all been identified as mechanisms of bladder dysfunction [175] and act in part by disrupting coordination between the detrusor, urinary sphincter, and central nervous system $[173,174]$. While there are many examples of environmental chemicals causing neuropathies, the consequences on lower urinary tract function are rarely examined.

\subsection{The Relationship between LUTD and Comorbidities}

Recent studies connect LUTD to other diseases. For example, people with cardiovascular disease, diabetes and obstructive sleep apnea are at increased risk of developing LUTD [176-179]. A common thread linking these diseases is a change in hemodynamics connected to ischemic injury [180-182], a factor that independently drives LUTD in mice [174]. Environmental chemical exposures have been linked to cardiovascular disease and diabetes [183-186], and this is another mechanism by which they may drive LUTD.

\section{Mouse Research Models of Male LUTD}

Here we describe animal models used to study various etiologies of LUTD. While it is important to realize that results from animal models are not always transferable to humans, it is also crucial to highlight that animal models are used in preclinical trails to test the safety and efficacy of drugs and are an invaluable tool to use in toxicological studies.

\subsection{Benign Prostatic Hyperplasia}

A variety of genetically engineered mouse models have been used to drive expression of growth factors or mitogenic hormones in the prostate. Androgen responsive promoter sequences, androgen-induced cre recombinase or viral promoters are used to target genetic modifications to mouse prostate tissue and overexpress fibroblast growth factor 2 or fibroblast growth factor 3 to drive epithelial BPH [187-189], overexpress prolactin [190-193] or interleukin 1 alpha [194] to drive epithelial and stromal BPH and prostate inflammation, delete serine/threonine kinase 11 to promote stromal BPH in the periurethral region [195], or genetically modify other sequences. Expression of an activated form of P110 alpha, the catalytic subunit of PI3K, in mouse prostate epithelium also drives epithelial BPH in mice but accompanied with a stark fibrotic response in prostatic stroma [196]. Many of these genetically engineered mouse models were created before contemporary methods were optimized for mouse urinary physiology phenotyping. The historical goal was to use genetically engineered mice to identify molecular mediators of BPH and test efficacy of drugs and dietary substances for relieving BPH in preclinical model species. While geneti- 
cally engineered mouse models are useful for understanding homeostatic mechanisms of prostate cell proliferation, it is becoming clear that BPH is not always linked to LUTD in men [197], and it remains important to characterize urinary physiology in these mice as a more relevant endpoint for male LUTD.

\subsection{Mouse Models of Prostate Inflammation}

Histological inflammation of the human prostate is extremely common: in one study, it was detected in nearly $80 \%$ of prostate biopsy specimens from $60+$ year old men and was strongly associated with urinary voiding symptoms [198]. Prostate infection by ascending microbes is one potential mechanism of prostate inflammation and supported by the frequent encounter of bacteria in human prostate tissue specimens [199-201]. One strategy for driving prostate inflammation in mice involves urethral catheterization and delivery of uropathogenic E. coli. A variety of isolates have been used (E. coli UTI89, 4017, 1677 and CP-1), ranging from those collected as clinical urine isolates from women with bladder infections, to others collected from men with pelvic pain [202,203]. The pattern of inflammation (acute vs. chronic) depends in part on mouse strain used [204] and method of E. coli delivery (single vs. multiple inoculations, catheter size, instillation volume and bacterial load). It is essential to control these variables carefully when considering experimental design, and mice instilled with sterile saline (sham operated mice) are an essential component of experimental design because urethral catheterization can itself induce trauma, urethritis, and changes in urinary voiding physiology [144]. Prostatic E. coli infection is linked to prostate fibrosis and changes in voiding patterns in mice, but voiding patterns differ between $E$. coli strains and methods of infection and can include high volume, low frequency voiding [144] or low volume, high frequency voiding [107,205,206].

Many men with histological prostatitis present with a pattern of prostatic infiltrate consistent with prostate autoimmunity [207-209], an observation co-opted for the design of mouse models. The prostate ovalbumin expressing transgenic-3 mouse expresses ovalbumin under the control of the androgen-responsive probasin promoter [210,211]. Autologous splenocytes are activated in vitro and transplanted to drive T-cell mediated prostate autoimmunity and inflammation [207]. While the pattern of inflammation and mechanisms of cell proliferation have been carefully studied in this mouse, the urinary physiology phenotype is not well characterized. The experimental autoimmune prostatitis mouse model involves repeated intradermal injections of rat prostate homogenate into mice to drive a T-cell based autoimmune reaction that has been used to examine mechanisms of male LUTD and chronic pelvic pain [212,213].

A non-bacterial mouse model of prostate inflammation was created based on observations that IL- 1 beta abundance increases after intraprostatic injection of noxious agents or uropathogenic E. coli infection [214-217] and that Prostatic IL-1 beta abundance is elevated in humans with histological BPH and correlates with LUTS and chronic pelvic pain [218-222]. This mouse model utilizes the Tet-On system which induces expression of a gene in the presence of doxycycline and is tunable, with stronger transgene expression with doxycycline dose [223]. A double transgene of Hoxb13-rTA transgene and a TetO-IL1 beta responder is used to drive IL- 1 beta in prostatic epithelial cells [223,224]. The urinary metabolomic proteomic signatures of this mouse have been described, but the urinary physiology phenotype remains to be determined [224,225].

A recent mouse model of prostate inflammation is based off observations that prostate secretory proteins are leaked into prostate stroma of some men with LUTD and accompanied with patchy loss of the adherens junction protein e-cadherin, suggesting a loss of prostate barrier function [226]. Genetic depletion of e-cadherin in mouse prostate epithelium increases prostate mass and cell proliferation, thickens prostate stroma, and increases voiding frequency while reducing voided urine volume, and increases spontaneous bladder contractions [227]. 


\subsection{Mouse Models of Partial Bladder Outlet Obstruction ( $p B O O$ )}

Surgical approaches were first used to model pBOO in male mice. One approach involves a retropubic incision to apply and cinch a suture or metal ring around the bladder neck or pelvic urethra to drive bladder compensation and overactive bladder, and later bladder decompensation, detrusor underactivity, fibrosis, and loss of muscle mass [228-231]. The mouse model has been essential for recognizing new druggable pathways for restoring function to the decompensated bladder [232].

Treatment with exogenous androgens combined with estrogens is a non-surgical method to drive $\mathrm{BOO}$ in mice. Mice are given slow-release implants of androgen (testosterone or dihydrotestosterone) in combination with slow-release implants of estrogen (17beta-estradiol or diethylstilbesterol). The combination of androgen plus estrogen is necessary for prostate gland maintenance, as estrogens delivered to male mice in the absence of androgens disrupts hypothalamic/pituitary/gonadal signaling and cause prostate gland atrophy [128]. Genetically engineered mice that overexpress aromatase are also used to recapitulate the endocrine environment of advancing age [129,233]. Male mice treated with androgen and estrogen develop progressive LUTD, with evidence of disease processes (increased bladder weight as evidence of hypertrophy/compensation for BOO) occurring as early as two weeks after treatment [124]. Sustained exposure to exogenous androgens and estrogens elicits a variety of changes to the male lower urinary tract of multiple species, including prostatic hypertrophy and inflammation, urethral narrowing and abnormal urethral muscle tone, urinary dysfunction with progressive onset, bladder overactivity and eventual decompensation [124,127-131,133,234-238]. Estrogen receptor activation is a key driver of urinary dysfunction, as exogenous estradiol given to male mice drives urinary retention in the absence of exogenous testosterone [239] and estrogen receptor 1 is required for urinary retention and voiding dysfunction from exogenous testosterone and 17beta-estradiol in mice [237]. An important consideration when exogenous androgen and estrogen are used to drive male LUTD, especially when incorporating genetic changes to identify mechanisms, is that hormone responsiveness, disease onset, progression and severity are influenced by genetic background and mouse strain [234]. The delivery system of exogenous androgens and estrogens should be considered if using hormones to drive LUTD for a toxicology study. Compressed pellets of androgens and estrogens can be crushed when animals are restrained for chemical exposure (injection) [21]. Silastic capsule preparations of androgens and estrogens are more durable [240].

\subsection{Mouse Models of Overactive Bladder (OAB)}

$\mathrm{OAB}$ can be induced by ischemic injury $[24,93,241]$. A balloon catheter is passed through the iliac artery and inflated, then withdrawn to cause endothelial damage [241]. This injury is combined with a cholesterol enriched diet to cause bladder arterial occlusions and chronic bladder ischemia [206]. This model results in increased voiding frequency but decreased voided volume, and more frequent non-voiding bladder contractions in rats [241].

$\mathrm{OAB}$ can also be induced by the introduction of noxious stimuli (acetic acid, hydrochloric acid, and others) into the bladder [242,243]. Chemical induced OAB decreases the inter-voiding interval of anesthetized mice, reduces bladder capacity, and sensitizes afferent nerves [243-246].

\subsection{Mouse Models of Detrusor Sphincter Dyssynergia (DSD)}

The most common approach to evoke detrusor sphincter dyssynergia is to induce spinal cord injury under anesthesia [247]. Urine must be manually expressed at least three times per day until the micturition reflexes recover (10-14 days), then once per day [247]. Cystometry profiling of injured mice reveals increased activity of the external urethral sphincter coupled with increased urethral pressure and voiding pressure, increased frequency and magnitude of non-voiding contractions, and increased bladder capacity $[247,248]$. 


\section{Conclusions}

Lower urinary physiology is extremely complex, shaped by contributions from the urethra, prostate, bladder, ascending and descending neural pathways, and the brain. Despite an extremely high prevalence of male LUTD and devastating impacts on society, LUTD mechanisms and factors that influence LUTD severity are poorly understood. Environmental contributions to LUTD remain almost completely unexamined. We provided this overview of male lower urinary tract anatomy, physiology, and cell biology, described known disease mechanisms, and highlighted knowledge gaps that require additional research to direct new attention from toxicologists and environmental health specialists to this widespread disease. We detailed examples of environmental chemicals that perturb urinary tract function and described mouse models of LUTD with the intention that public health specialists, epidemiologists and toxicologists will consider LUTD research in toxicity assessments. Future risk mitigation strategies will likely be critical to reducing the burden and severity of LUTD in aging adults.

Author Contributions: Conceptualization, N.T.P. and C.M.V. writing-original draft preparation, N.T.P. and C.M.V.; writing-review and editing, N.T.P. and C.M.V. All authors have read and agreed to the published version of the manuscript.

Funding: This research was funded by National Institutes of Health Grants R01 ES001332 and U54 DK104310, T32 ES007015, and the UW-Madison Advanced Opportunity Fellowship. The content is solely the responsibility of the authors and does not necessarily represent the official views of the National Institutes of Health.

Institutional Review Board Statement: Not Applicable.

Informed Consent Statement: Not Applicable.

Data Availability Statement: This paper does not report any data that has not been published elsewhere.

Conflicts of Interest: The authors declare no conflict of interest.

\section{References}

1. Jacobsen, S.J.; Jacobson, D.J.; Girman, C.J.; Roberts, R.O.; Rhodes, T.; Guess, H.A.; Lieber, M.M. Natural history of prostatism: Risk factors for acute urinary retention. J. Urol. 1997, 158, 481-487. [CrossRef]

2. Roehrborn, C.G.; Malice, M.-P.; Cook, T.J.; Girman, C.J. Clinical predictors of spontaneous acute urinary retention in men with luts and clinical bph: A comprehensive analysis of the pooled placebo groups of several large clinical trials. Urology 2001, 58, 210-216. [CrossRef]

3. Winters, J.C.; Dmochowski, R.R.; Goldman, H.B.; Herndon, C.D.; Kobashi, K.C.; Kraus, S.R.; Lemack, G.E.; Nitti, V.W.; Rovner, E.S.; Wein, A.J.; et al. Urodynamic studies in adults: AUA/SUFU guideline. J. Urol. 2012, 188, 2464-2472. [CrossRef]

4. Agarwal, A.; Eryuzlu, L.N.; Cartwright, R.; Thorlund, K.; Tammela, T.L.; Guyatt, G.H.; Auvinen, A.; Tikkinen, K.A. What is the most bothersome lower urinary tract symptom? Individual- and population-level perspectives for both men and women. Eur. Urol. 2014, 65, 1211-1217. [CrossRef]

5. Shah, H.N. Benign prostate hyperplasia and bladder stones: An update. Curr. Bladder Dysfunct. Rep. 2013, 8, 250-260. [CrossRef]

6. Wei, J.T.; Calhoun, E.; Jacobsen, S.J. Urologic diseases in america project: Benign prostatic hyperplasia. J. Urol. 2005, 173, 1256-1261. [CrossRef]

7. Launer, B.M.; McVary, K.T.; Ricke, W.A.; Lloyd, G.L. The rising worldwide impact of benign prostatic hyperplasia. BJU Int. 2021, 127, 722-728. [CrossRef]

8. Kobelt, G.; Borgstrom, F.; Mattiasson, A. Productivity, vitality and utility in a group of healthy professionally active individuals with nocturia. BJU Int. 2003, 91, 190-195. [CrossRef]

9. Cakir, O.O.; McVary, K.T. LUTS and sleep disorders: Emerging risk factor. Curr. Urol. Rep. 2012, 13, 407-412. [CrossRef]

10. Ancoli-Israel, S.; Bliwise, D.L.; Norgaard, J.P. The effect of nocturia on sleep. Sleep Med. Rev. 2011, 15, 91-97. [CrossRef]

11. Johnson, T.V.; Abbasi, A.; Ehrlich, S.S.; Kleris, R.S.; Owen-Smith, A.; Raison, C.L.; Master, V.A. IPSS quality of life question: A possible indicator of depression among patients with lower urinary tract symptoms. Can. J. Urol. 2012, 19, 6100-6104.

12. Rom, M.; Schatzl, G.; Swietek, N.; Rucklinger, E.; Kratzik, C. Lower urinary tract symptoms and depression. BJU Int. 2012, 110, E918-E921. [CrossRef]

13. Jepsen, J.V.; Bruskewitz, R.C. Recent developments in the surgical management of benign prostatic hyperplasia. Urology 1998, 51, 23-31. [CrossRef]

14. Chute, C.G.; Panser, L.A.; Girman, C.J.; Oesterling, J.E.; Guess, H.A.; Jacobsen, S.J.; Lieber, M.M. The prevalence of prostatism: A population-based survey of urinary symptoms. J. Urol. 1993, 150, 85-89. [CrossRef] 
15. Berry, S.J.; Coffey, D.S.; Walsh, P.C.; Ewing, L.L. The development of human benign prostatic hyperplasia with age. J. Urol. 1984, 132, 474-479. [CrossRef]

16. Hutchison, A.; Farmer, R.; Verhamme, K.; Berges, R.; Navarrete, R.V. The efficacy of drugs for the treatment of LUTS/BPH, a study in 6 European countries. Eur. Urol. 2007, 51, 207-216. [CrossRef]

17. Kirby, R.S.; Roehrborn, C.; Boyle, P.; Bartsch, G.; Jardin, A.; Cary, M.M.; Sweeney, M.; Grossman, E.B. Efficacy and tolerability of doxazosin and finasteride, alone or in combination, in treatment of symptomatic benign prostatic hyperplasia: The Prospective European doxazosin and combination therapy (PREDICT) trial. Urology 2003, 61, 119-126. [CrossRef]

18. Roehrborn, C.G. Efficacy of alpha-adrenergic receptor blockers in the treatment of male lower urinary tract symptoms. Rev. Urol. 2009,11, S1-S8

19. Keil Stietz, K.P.; Kennedy, C.L.; Sethi, S.; Valenzuela, A.; Nunez, A.; Wang, K.; Wang, Z.; Wang, P.; Spiegelhoff, A.; Puschner, B.; et al. In utero and lactational pcb exposure drives anatomic changes in the juvenile mouse bladder. Curr. Res. Toxicol. 2021, 2, 1-18. [CrossRef]

20. Turco, A.E.; Oakes, S.R.; Stietz, K.P.K.; Dunham, C.L.; Joseph, D.B.; Chathurvedula, T.S.; Girardi, N.M.; Schneider, A.J.; Gawdzik, J.; Sheftel, C.M.; et al. A neuroanatomical mechanism linking perinatal TCDD exposure to lower urinary tract dysfunction in adulthood. Dis. Model Mech. 2021, 14, 1-10. [CrossRef]

21. Turco, A.E.; Thomas, S.; Crawford, L.K.; Tang, W.; Peterson, R.E.; Li, L.; Ricke, W.A.; Vezina, C.M. In utero and lactational 2,3,7,8-tetrachlorodibenzo-p-dioxin (TCDD) exposure exacerbates urinary dysfunction in hormone-treated c57bl/6j mice through a non-malignant mechanism involving proteomic changes in the prostate that differ from those elicited by testosterone and estradiol. Am. J. Clin. Exp. Urol. 2020, 8, 59-72. [PubMed]

22. Middleton, L.W.; Shen, Z.; Varma, S.; Pollack, A.S.; Gong, X.; Zhu, S.; Zhu, C.; Foley, J.W.; Vennam, S.; Sweeney, R.T.; et al. Genomic analysis of benign prostatic hyperplasia implicates cellular re-landscaping in disease pathogenesis. JCI Insight 2019, 5, e129749. [CrossRef] [PubMed]

23. Joseph, D.B.; Henry, G.H.; Malewska, A.; Reese, J.C.; Mauck, R.J.; Gahan, J.C.; Hutchinson, R.C.; Mohler, J.L.; Roehrborn, C.G.; Strand, D.W. 5-alpha reductase inhibitors induce a prostate luminal to club cell transition in human benign prostatic hyperplasia. J. Pathol. 2021, 1-15. [CrossRef] [PubMed]

24. Joseph, D.B.; Henry, G.H.; Malewska, A.; Iqbal, N.S.; Ruetten, H.M.; Turco, A.E.; Abler, L.L.; Sandhu, S.K.; Cadena, M.T.; Malladi, V.S.; et al. Urethral luminal epithelia are castration-insensitive cells of the proximal prostate. Prostate 2020, 80, 872-884. [CrossRef] [PubMed]

25. Andersson, K.-E.; McCloskey, K.D. Lamina propria: The functional center of the bladder? Neurourol. Urodyn. 2014, 33, 9-16. [CrossRef] [PubMed]

26. Apodaca, G. The uroepithelium: Not just a passive barrier. Traffic 2004, 5, 117-128. [CrossRef] [PubMed]

27. Graham, E.; Chai, T.C. Dysfunction of bladder urothelium and bladder urothelial cells in interstitial cystitis. Curr. Urol. Rep. 2006, 7, 440-446. [CrossRef]

28. Guo, C.; Balsara, Z.R.; Hill, W.G.; Li, X. Stage- and subunit-specific functions of polycomb repressive complex 2 in bladder urothelial formation and regeneration. Development 2017, 144, 400-408. [CrossRef]

29. Khandelwal, P.; Abraham, S.N.; Apodaca, G. Cell biology and physiology of the uroepithelium. Am. J. Physiol. Ren. Physiol. 2009, 297, F1477-F1501. [CrossRef]

30. Hurst, R.E. Structure, function, and pathology of proteoglycans and glycosaminoglycans in the urinary tract. World J. Urol. 1994, 12, 3-10. [CrossRef]

31. Hu, P.; Deng, F.-M.; Liang, F.-X.; Hu, C.-M.; Auerbach, A.B.; Shapiro, E.; Wu, X.-R.; Kachar, B.; Sun, T.-T. Ablation of uroplakin III gene results in small urothelial plaques, urothelial leakage, and vesicoureteral reflux. J. Cell Biol. 2000, 151, 961-972. [CrossRef]

32. Wu, X.R.; Kong, X.P.; Pellicer, A.; Kreibich, G.; Sun, T.T. Uroplakins in urothelial biology, function, and disease. Kidney Int. 2009, 75, 1153-1165. [CrossRef]

33. Kątnik-Prastowska, I.; Lis, J.; Matejuk, A. Glycosylation of uroplakins. Implications for bladder physiopathology. Glycoconj. J. 2014, 31, 623-636. [CrossRef]

34. Gandhi, D.; Molotkov, A.; Batourina, E.; Schneider, K.; Dan, H.; Reiley, M.; Laufer, E.; Metzger, D.; Liang, F.; Liao, Y.; et al. Retinoid signaling in progenitors controls specification and regeneration of the urothelium. Develop. Cell 2013, 26, 469-482. [CrossRef]

35. Sutherland Ronald, S.; Baskin Laurence, S.; Hayward Simon, W.; Cunha Gerald, R. Regeneration of bladder urothelium, smooth muscle, blood vessels and nerves into an acellular tissue matrix. J. Urol. 1996, 156, 571-577. [CrossRef]

36. Hicks, R.M. The mammalian urinary bladderan accommodating organ. Biol. Rev. 1975, 50, 215-246. [CrossRef]

37. Joseph, D.B.; Chandrashekar, A.S.; Abler, L.L.; Chu, L.F.; Thomson, J.A.; Mendelsohn, C.; Vezina, C.M. In vivo replacement of damaged bladder urothelium by Wolffian duct epithelial cells. Proc. Natl. Acad. Sci. USA 2018, 115, 8394-8399. [CrossRef]

38. Cox, P.J. Cyclophosphamide cystitis-Identification of acrolein as the causative agent. Biochem. Pharmacol. 1979, 28, 2045-2049. [CrossRef]

39. Brock, N.; Stekar, J.; Pohl, J.; Niemeyer, U.; Scheffler, G. Acrolein, the causative factor of urotoxic side-effects of cyclophosphamide, ifosfamide, trofosfamide and sufosfamide. Arzneimittelforschung 1979, 29, 659-661.

40. Al-Rawithi, S.; El-Yazigi, A.; Ernst, P.; Al-Fiar, F.; Nicholls, P.J. Urinary excretion and pharmacokinetics of acrolein and its parent drug cyclophosphamide in bone marrow transplant patients. Bone Marrow Transplant. 1998, 22, 485-490. [CrossRef] 
41. Andersson, K.E.; Nomiya, M.; Yamaguchi, O. Chronic pelvic ischemia: Contribution to the pathogenesis of lower urinary tract symptoms (LUTS): A new target for pharmacological treatment? Low Urin. Tract Symptoms 2015, 7, 1-8. [CrossRef]

42. Birder, L.A.; Kanai, A.J.; de Groat, W.C.; Kiss, S.; Nealen, M.L.; Burke, N.E.; Dineley, K.E.; Watkins, S.; Reynolds, I.J.; Caterina, M.J. Vanilloid receptor expression suggests a sensory role for urinary bladder epithelial cells. Proc. Natl. Acad. Sci. USA 2001, 98, 13396-13401. [CrossRef]

43. Ferguson, D.R.; Kennedy, I.; Burton, T.J. ATP is released from rabbit urinary bladder epithelial cells by hydrostatic pressure changes-Possible sensory mechanism? J. Physiol. 1997, 505, 503-511. [CrossRef]

44. Wiseman, O.J.; Fowler, C.J.; Landon, D.N. The role of the human bladder lamina propria myofibroblast. BJU Int. 2003, 91, 89-93. [CrossRef]

45. Aitken, K.J.; Bägli, D.J. The bladder extracellular matrix. Part I: Architecture, development and disease. Nat. Rev. Urol. 2009, 6, 596-611. [CrossRef]

46. Andersson, K.-E.; Arner, A. Urinary bladder contraction and relaxation: Physiology and pathophysiology. Physiol. Rev. 2004, 84, 935-986. [CrossRef]

47. Sjuve, R.; Haase, H.; Ekblad, E.; Malmqvist, U.; Morano, I.; Arner, A. Increased expression of non-muscle myosin heavy chain-B in connective tissue cells of hypertrophic rat urinary bladder. Cell Tissue Res. 2001, 304, 271-278. [CrossRef]

48. Seki, T.; Naito, I.; Oohashi, T.; Sado, Y.; Ninomiya, Y. Differential expression of type IV collagen isoforms, alpha5(IV) and alpha6(IV) chains, in basement membranes surrounding smooth muscle cells. Histochem. Cell Biol. 1998, 110, 359-366. [CrossRef]

49. Gilpin, S.A.; Gilpin, C.J.; Dixon, J.S.; Gosling, J.A.; Kirby, R.S. The effect of age on the autonomic innervation of the urinary bladder. Br. J. Urol. 1986, 58, 378-381. [CrossRef]

50. Erdem, N.; Chu, F.M. Management of overactive bladder and urge urinary incontinence in the elderly patient. Am. J. Med. 2006, 119, 29-36. [CrossRef]

51. Drake, M.J.; Mills, I.W.; Gillespie, J.I. Model of peripheral autonomous modules and a myovesical plexus in normal and overactive bladder function. Lancet 2001, 358, 401-403. [CrossRef]

52. Häbler, H.J.; Jänig, W.; Koltzenburg, M. Activation of unmyelinated afferent fibres by mechanical stimuli and inflammation of the urinary bladder in the cat. J. Physiol. 1990, 425, 545-562. [CrossRef]

53. Morrison, J. The activation of bladder wall afferent nerves. Exp. Physiol. 1999, 84, 131-136. [CrossRef]

54. Tennyson, L.E.; Tai, C.; Chermansky, C.J. Using the native afferent nervous system to sense bladder fullness: State of the art. Curr. Bladder Dysfunct. Rep. 2016, 11, 346-349. [CrossRef]

55. Marshall, K.L.; Saade, D.; Ghitani, N.; Coombs, A.M.; Szczot, M.; Keller, J.; Ogata, T.; Daou, I.; Stowers, L.T.; Bönnemann, C.G.; et al. PIEZO2 in sensory neurons and urothelial cells coordinates urination. Nature 2020, 588, 290-295. [CrossRef]

56. Dalghi, M.G.; Ruiz, W.G.; Clayton, D.R.; Montalbetti, N.; Daugherty, S.L.; Beckel, J.M.; Carattino, M.D.; Apodaca, G. Functional roles for PIEZO1 and PIEZO2 in urothelial mechanotransduction and lower urinary tract interoception. JCI Insight 2021, 6, e152984. [CrossRef]

57. Ford, A.P.; Cockayne, D.A. ATP and P2X purinoceptors in urinary tract disorders. In Handbook of Experimental Pharmacology; Springer: Berlin/Heidelberg, Germany, 2011; pp. 485-526.

58. Vlaskovska, M.; Kasakov, L.; Rong, W.; Bodin, P.; Bardini, M.; Cockayne, D.A.; Ford, A.P.; Burnstock, G. P2X3 knock-out mice reveal a major sensory role for urothelially released. ATP J. Neurosci. 2001, 21, 5670-5677. [CrossRef]

59. Ferguson, A.C.; Sutton, B.W.; Boone, T.B.; Ford, A.P.; Munoz, A. Inhibition of urothelial P2X3 receptors prevents desensitization of purinergic detrusor contractions in the rat bladder. BJU Int. 2015, 116, 293-301. [CrossRef]

60. Heppner, T.J.; Tykocki, N.R.; Hill-Eubanks, D.; Nelson, M.T. Transient contractions of urinary bladder smooth muscle are drivers of afferent nerve activity during filling. J. Gen. Physiol. 2016, 147, 323-335. [CrossRef]

61. Barrington, F.J.F. The effect of lesions of the hind- and mid-brain on micturition in the cat. Q. J. Exp. Physiol. 1925, 15, 81-102. [CrossRef]

62. Sasaki, M. Role of Barrington's nucleus in micturition. J. Comp. Neurol. 2005, 493, 21-26. [CrossRef]

63. Westlund, K.N.; Coulter, J.D. Descending projections of the locus coeruleus and subcoeruleus/medial parabrachial nuclei in monkey: Axonal transport studies and dopamine- $\beta$-hydroxylase immunocytochemistry. Brain Res. Rev. 1980, 2, $235-264$. [CrossRef]

64. Martin, G.F.; Humbertson, A.O., Jr.; Laxson, L.C.; Panneton, W.M.; Tschismadia, I. Spinal projections from the mesencephalic and pontine reticular formation in the north American opossum: A study using axonal transport techniques. J. Comp. Neurol. 1979, 187, 373-399. [CrossRef]

65. Loewy, A.D.; Saper, C.B.; Baker, R.P. Descending projections from the pontine micturition center. Brain Res. 1979, $172,533-538$. [CrossRef]

66. Holstege, G.; Kuypers, H.G.J.M.; Boer, R.C. Anatomical evidence for direct brain stem projections to the somatic motoneuronal cell groups and autonomic preganglionic cell groups in cat spinal cord. Brain Res. 1979, 171, 329-333. [CrossRef]

67. Blok, B.F.M.; Holstege, G. Direct projections from the periaqueductal gray to the pontine micturition center (M-region). An anterograde and retrograde tracing study in the cat. Neurosci. Lett. 1994, 166, 93-96. [CrossRef]

68. Verstegen, A.M.J.; Vanderhorst, V.; Gray, P.A.; Zeidel, M.L.; Geerling, J.C. Barrington's nucleus: Neuroanatomic landscape of the mouse "pontine micturition center". J. Comp. Neurol. 2017, 525, 2287-2309. [CrossRef] 
69. Verstegen, A.M.J.; Klymko, N.; Zhu, L.; Mathai, J.C.; Kobayashi, R.; Venner, A.; Ross, R.A.; VanderHorst, V.G.; Arrigoni, E.; Geerling, J.C.; et al. Non-crh glutamatergic neurons in barrington's nucleus control micturition via glutamatergic afferents from the midbrain and hypothalamus. Curr. Biol. 2019, 29, 2775-2789.e2777. [CrossRef]

70. Keller, J.A.; Chen, J.; Simpson, S.; Wang, E.H.-J.; Lilascharoen, V.; George, O.; Lim, B.K.; Stowers, L. Voluntary urination control by brainstem neurons that relax the urethral sphincter. Nat. Neurosci. 2018, 21, 1229-1238. [CrossRef]

71. Hou, X.H.; Hyun, M.; Taranda, J.; Huang, K.W.; Todd, E.; Feng, D.; Atwater, E.; Croney, D.; Zeidel, M.L.; Osten, P. Central control circuit for context-dependent micturition. Cell 2016, 167, 73-86. [CrossRef]

72. Griffiths, D.; Holstege, G.; Dalm, E.; Wall, H.D. Control and coordination of bladder and urethral function in the brainstem of the cat. Neurourol. Urodyn. 1990, 9, 63-82. [CrossRef]

73. Van Batavia, J.P.; Butler, S.; Lewis, E.; Fesi, J.; Canning, D.A.; Vicini, S.; Valentino, R.J.; Zderic, S.A. Corticotropin-releasing hormone from the pontine micturition center plays an inhibitory role in micturition. J. Neurosci. 2021, 41, 7314-7325. [CrossRef]

74. Siblerud, R.; Mutter, J.; Moore, E.; Naumann, J.; Walach, H. A hypothesis and evidence that mercury may be an etiological factor in Alzheimer's disease. Int. J. Environ. Res. Public Health 2019, 16, 5152. [CrossRef]

75. Tchounwou, P.B.; Ayensu, W.K.; Ninashvili, N.; Sutton, D. Review: Environmental exposure to mercury and its toxicopathologic implications for public health. Environ. Toxicol. 2003, 18, 149-175. [CrossRef]

76. Sindhu, K.K.; Sutherling, W.W. Role of lead in the central nervous system: Effect on electroencephlography, evoked potentials, electroretinography, and nerve conduction. Neurodiagn. J. 2015, 55, 107-121. [CrossRef]

77. Mason, L.H.; Harp, J.P.; Han, D.Y. Pb neurotoxicity: Neuropsychological effects of lead toxicity. Biomed. Res. Int. 2014, $2014,840547$. [CrossRef]

78. Naughton, S.X.; Terry, A.V. Neurotoxicity in acute and repeated organophosphate exposure. Toxicology 2018, 408, 101-112. [CrossRef]

79. Mochizuki, H. Arsenic neurotoxicity in humans. Int. J. Mol. Sci. 2019, 20, 3418. [CrossRef]

80. Richardson, J.R.; Fitsanakis, V.; Westerink, R.H.S.; Kanthasamy, A.G. Neurotoxicity of pesticides. Acta Neuropathol. 2019, 138, 343-362. [CrossRef]

81. Sethi, S.; Morgan, R.K.; Feng, W.; Lin, Y.; Li, X.; Luna, C.; Koch, M.; Bansal, R.; Duffel, M.W.; Puschner, B.; et al. Comparative analyses of the 12 most abundant PCB congeners detected in human maternal serum for activity at the thyroid hormone receptor and ryanodine receptor. Environ. Sci. Technol. 2019, 53, 3948-3958. [CrossRef]

82. Rude, K.M.; Keogh, C.E.; Gareau, M.G. The role of the gut microbiome in mediating neurotoxic outcomes to PCB exposure Neurotoxicology 2019, 75, 30-40. [CrossRef] [PubMed]

83. Galgano, S.J.; Sivils, C.; Selph, J.P.; Sanyal, R.; Lockhart, M.E.; Zarzour, J.G. The male urethra: Imaging and surgical approach for common pathologies. Curr. Probl. Diagn. Radiol. 2021, 50, 410-418. [CrossRef] [PubMed]

84. Georgas, K.M.; Armstrong, J.; Keast, J.R.; Larkins, C.E.; McHugh, K.M.; Southard-Smith, E.M.; Cohn, M.J.; Batourina, E.; Dan, H.; Schneider, K.; et al. An illustrated anatomical ontology of the developing mouse lower urogenital tract. Development 2015, 142, 1893-1908. [CrossRef] [PubMed]

85. Morales, O.; Romanus, R. Urethrography in the male: The boundaries of the different urethral parts and detail studies of the urethral mucous membrane and its motility. J. Urol. 1955, 73, 162-171. [CrossRef]

86. Henry, G.H.; Malewska, A.; Joseph, D.B.; Malladi, V.S.; Lee, J.; Torrealba, J.; Mauck, R.J.; Gahan, J.C.; Raj, G.V.; Roehrborn, C.G.; et al. A cellular anatomy of the normal adult human prostate and prostatic urethra. Cell Rep. 2018, 25, 3530-3542.e3535. [CrossRef]

87. Crowley, L.; Cambuli, F.; Aparicio, L.; Shibata, M.; Robinson, B.D.; Xuan, S.; Li, W.; Hibshoosh, H.; Loda, M.; Rabadan, R. A single-cell atlas of the mouse and human prostate reveals heterogeneity and conservation of epithelial progenitors. Elife $\mathbf{2 0 2 0}$ 9, e59465. [CrossRef]

88. Zhai, J.; Insel, M.; Addison, K.J.; Stern, D.A.; Pederson, W.; Dy, A.; Rojas-Quintero, J.; Owen, C.A.; Sherrill, D.L.; Morgan, W.; et al. Club cell secretory protein deficiency leads to altered lung function. Am. J. Respir. Crit. Care Med. 2019, 199, 302-312. [CrossRef]

89. Rawlins, E.L.; Okubo, T.; Xue, Y.; Brass, D.M.; Auten, R.L.; Hasegawa, H.; Wang, F.; Hogan, B.L. The role of Scgb1a1+ Clara cells in the long-term maintenance and repair of lung airway, but not alveolar, epithelium. Cell Stem Cell 2009, 4, 525-534. [CrossRef]

90. Hong, K.U.; Reynolds, S.D.; Giangreco, A.; Hurley, C.M.; Stripp, B.R. Clara cell secretory protein-expressing cells of the airway neuroepithelial body microenvironment include a label-retaining subset and are critical for epithelial renewal after progenitor cell depletion. Am. J. Respir. Cell Mol. Biol. 2001, 24, 671-681. [CrossRef]

91. Montoro, D.T.; Haber, A.L.; Biton, M.; Vinarsky, V.; Lin, B.; Birket, S.E.; Yuan, F.; Chen, S.; Leung, H.M.; Villoria, J.; et al. A revised airway epithelial hierarchy includes CFTR-expressing ionocytes. Nature 2018, 560, 319-324. [CrossRef]

92. Deprez, M.; Zaragosi, L.E.; Truchi, M.; Becavin, C.; Ruiz García, S.; Arguel, M.J.; Plaisant, M.; Magnone, V.; Lebrigand, K.; Abelanet, S.; et al. A single-cell atlas of the human healthy airways. Am. J. Respir. Crit. Care Med. 2020, 202, 1636-1645. [CrossRef] [PubMed]

93. Jung, J.; Ahn, H.K.; Huh, Y. Clinical and functional anatomy of the urethral sphincter. Int. Neurourol. J. 2012, 16, 102-106. [CrossRef] [PubMed]

94. Oelrich, T.M. The urethral sphincter muscle in the male. Am. J. Anat. 1980, 158, 229-246. [CrossRef]

95. Nyangoh Timoh, K.; Moszkowicz, D.; Creze, M.; Zaitouna, M.; Felber, M.; Lebacle, C.; Diallo, D.; Martinovic, J.; Tewari, A.; Lavoué, V.; et al. The male external urethral sphincter is autonomically innervated. Clin. Anat. 2021, 34, 263-271. [CrossRef] [PubMed] 
96. McNeal, J.E. The zonal anatomy of the prostate. Prostate 1981, 2, 35-49. [CrossRef]

97. Verze, P.; Cai, T.; Lorenzetti, S. The role of the prostate in male fertility, health and disease. Nat. Rev. Urol. 2016, 13, 379-386. [CrossRef] [PubMed]

98. Medved, M.; Sammet, S.; Yousuf, A.; Oto, A. MR imaging of the prostate and adjacent anatomic structures before, during, and after ejaculation: Qualitative and quantitative evaluation. Radiology 2014, 271, 452-460. [CrossRef]

99. Joseph, D.B.; Henry, G.H.; Malewska, A.; Reese, J.C.; Mauck, R.J.; Gahan, J.C.; Hutchinson, R.C.; Malladi, V.S.; Roehrborn, C.G.; Vezina, C.M.; et al. Single-cell analysis of mouse and human prostate reveals novel fibroblasts with specialized distribution and microenvironment interactions. J. Pathol. 2021, 255, 141-154. [CrossRef]

100. McNeal, J.; Kindrachuk, R.; Freiha, F.; Bostwick, D.; Redwine, E.; Stamey, T. Patterns of progression in prostate cancer. Lancet 1986, 327, 60-63. [CrossRef]

101. Frick, J.; Aulitzky, W. Physiology of the prostate. Infection 1991, 19, S115-S118. [CrossRef]

102. Lee, C.H.; Akin-Olugbade, O.; Kirschenbaum, A. Overview of prostate anatomy, histology, and pathology. Endocrinol. Metab. Clin. N. Am. 2011, 40, 565-575. [CrossRef] [PubMed]

103. Yu, C.; Hu, K.; Nguyen, D.; Wang, Z.A. From genomics to functions: Preclinical mouse models for understanding oncogenic pathways in prostate cancer. Am. J. Cancer Res. 2019, 9, 2079-2102.

104. Liu, T.T.; Thomas, S.; McLean, D.T.; Roldan-Alzate, A.; Hernando, D.; Ricke, E.A.; Ricke, W.A. Prostate enlargement and altered urinary function are part of the aging process. Aging 2019, 11, 2653-2669. [CrossRef]

105. Huggins, C. The etiology of benign prostatic hypertrophy. Bull. N. Y. Acad. Med. 1947, 23, 696-704. [PubMed]

106. Ittmann, M. Anatomy and histology of the human and murine prostate. Cold Spring Harb. Perspect. Med. 2018, 8, a030346. [CrossRef] [PubMed]

107. Pattabiraman, G.; Bell-Cohn, A.J.; Murphy, S.F.; Mazur, D.J.; Schaeffer, A.J.; Thumbikat, P. Mast cell function in prostate inflammation, fibrosis, and smooth muscle cell dysfunction. Am. J. Physiol. Ren. Physiol. 2021, 321, F466-F479. [CrossRef] [PubMed]

108. Thielen, J.L.; Volzing, K.G.; Collier, L.S.; Green, L.E.; Largaespada, D.A.; Marker, P.C. Markers of prostate region-specific epithelial identity define anatomical locations in the mouse prostate that are molecularly similar to human prostate cancers. Differentiation 2007, 75, 49-61. [CrossRef]

109. Cunha, G.R.; Vezina, C.M.; Isaacson, D.; Ricke, W.A.; Timms, B.G.; Cao, M.; Franco, O.; Baskin, L.S. Development of the human prostate. Differentiation 2018, 103, 24-45. [CrossRef]

110. Tubaro, A.; Mariani, S.; De Nunzio, C.; Miano, R. Bladder weight and detrusor thickness as parameters of progression of benign prostatic hyperplasia. Curr. Opin. Urol. 2010, 20, 37-42. [CrossRef]

111. Kita, M.; Yunoki, T.; Takimoto, K.; Miyazato, M.; Kita, K.; de Groat, W.C.; Kakizaki, H.; Yoshimura, N. Effects of bladder outlet obstruction on properties of Ca2+-activated $\mathrm{K}+$ channels in rat bladder. Am. J. Physiol. Regul. Integr. Comp. Physiol. 2010, 298, R1310-R1319. [CrossRef]

112. Sugaya, K.; de Goat, W.C. Excitatory and inhibitory influence of pathways in the pelvic nerve on bladder activity in rats with bladder outlet obstruction. LUTS Low. Urin. Tract Symptoms 2009, 1, 51-55. [CrossRef] [PubMed]

113. Gosling, J.A.; Kung, L.S.; Dixon, J.S.; Horan, P.; Whitbeck, C.; Levin, R.M. Correlation between the structure and function of the rabbit urinary bladder following partial outlet obstruction. J. Urol. 2000, 163, 1349-1356. [CrossRef]

114. Kojima, M.; Inui, E.; Ochiai, A.; Naya, Y.; Kamoi, K.; Ukimura, O.; Watanabe, H. Reversible change of bladder hypertrophy due to benign prostatic hyperplasia after surgical relief of obstruction. J. Urol. 1997, 158, 89-93. [CrossRef] [PubMed]

115. Tubaro, A.; Carter, S.; Hind, A.; Vicentini, C.; Miano, L. A prospective study of the safety and efficacy of suprapubic transvesical prostatectomy in patients with benign prostatic hyperplasia. J. Urol. 2001, 166, 172-176. [CrossRef]

116. Fibbi, B.; Penna, G.; Morelli, A.; Adorini, L.; Maggi, M. Chronic inflammation in the pathogenesis of benign prostatic hyperplasia. Int. J. Androl. 2010, 33, 475-488. [CrossRef]

117. Bierhoff, E.; Vogel, J.; Benz, M.; Giefer, T.; Wernert, N.; Pfeifer, U. Stromal nodules in benign prostatic hyperplasia. Eur. Urol. 1996, 29, 345-354. [CrossRef]

118. Meigs, J.B.; Mohr, B.; Barry, M.J.; Collins, M.M.; McKinlay, J.B. Risk factors for clinical benign prostatic hyperplasia in a community-based population of healthy aging men. J. Clin. Epidemiol. 2001, 54, 935-944. [CrossRef]

119. Michel, M.C.; Mehlburger, L.; Schumacher, H.; Bressel, H.U.; Goepel, M. Effect of diabetes on lower urinary tract symptoms in patients with benign prostatic hyperplasia. J. Urol. 2000, 163, 1725-1729. [CrossRef]

120. Verhamme, K.M.; Dieleman, J.P.; Bleumink, G.S.; van der Lei, J.; Sturkenboom, M.C.; Artibani, W.; Begaud, B.; Berges, R.; Borkowski, A.; Chappel, C.R.; et al. Incidence and prevalence of lower urinary tract symptoms suggestive of benign prostatic hyperplasia in primary care-The Triumph project. Eur. Urol. 2002, 42, 323-328. [CrossRef]

121. McNeal, J. Pathology of benign prostatic hyperplasia. Insight into etiology. Urol. Clin. N. Am. 1990, 17, 477-486. [CrossRef]

122. Vermeulen, A. Decreased androgen levels and obesity in men. Ann. Med. 1996, 28, 13-15. [CrossRef] [PubMed]

123. Krieg, M.; Nass, R.; Tunn, S. Effect of aging on endogenous level of 5 alpha-dihydrotestosterone, testosterone, estradiol, and estrone in epithelium and stroma of normal and hyperplastic human prostate. J. Clin. Endocrinol. Metab. 1993, 77, 375-381. [PubMed] 
124. Nicholson, T.M.; Ricke, E.A.; Marker, P.C.; Miano, J.M.; Mayer, R.D.; Timms, B.G.; vom Saal, F.S.; Wood, R.W.; Ricke, W.A. Testosterone and $17 \beta$-estradiol induce glandular prostatic growth, bladder outlet obstruction, and voiding dysfunction in male mice. Endocrinology 2012, 153, 5556-5565. [CrossRef] [PubMed]

125. Belanger, A.; Candas, B.; Dupont, A.; Cusan, L.; Diamond, P.; Gomez, J.L.; Labrie, F. Changes in serum concentrations of conjugated and unconjugated steroids in 40- to 80-year-old men. J. Clin. Endocrinol. Metab. 1994, 79, 1086-1090. [PubMed]

126. Schatzl, G.; Brossner, C.; Schmid, S.; Kugler, W.; Roehrich, M.; Treu, T.; Szalay, A.; Djavan, B.; Schmidbauer, C.P.; Soregi, S.; et al. Endocrine status in elderly men with lower urinary tract symptoms: Correlation of age, hormonal status, and lower urinary tract function. The prostate study group of the Austrian society of urology. Urology 2000, 55, 397-402. [CrossRef]

127. Byron, J.K.; Taylor, K.H.; Phillips, G.S.; Stahl, M.S. Urethral sphincter mechanism incompetence in 163 neutered female dogs: Diagnosis, treatment, and relationship of weight and age at neuter to development of disease. J. Vet. Intern. Med. 2017, 31, 442-448. [CrossRef]

128. Bernoulli, J.; Yatkin, E.; Konkol, Y.; Talvitie, E.M.; Santti, R.; Streng, T. Prostatic inflammation and obstructive voiding in the adult Noble rat: Impact of the testosterone to estradiol ratio in serum. Prostate 2008, 68, 1296-1306. [CrossRef]

129. Streng, T.; Lehtoranta, M.; Poutanen, M.; Talo, A.; Lammintausta, R.; Santti, R. Developmental, estrogen induced infravesical obstruction is reversible in adult male rodents. J. Urol. 2002, 168, 2263-2268. [CrossRef]

130. Streng, T.K.; Talo, A.; Andersson, K.E.; Santti, R. A dose-dependent dual effect of oestrogen on voiding in the male mouse? BJU Int. 2005, 96, 1126-1130. [CrossRef]

131. Walsh, P.C.; Wilson, J.D. The induction of prostatic hypertrophy in the dog with androstanediol. J. Clin. Investig. 1976, 57, 1093-1097. [CrossRef]

132. Jeyaraj, D.A.; Udayakumar, T.S.; Rajalakshmi, M.; Pal, P.C.; Sharma, R.S. Effects of long-term administration of androgens and estrogen on rhesus monkey prostate: Possible induction of benign prostatic hyperplasia. J. Androl. 2000, 21, 833-841. [PubMed]

133. Tam, N.N.; Zhang, X.; Xiao, H.; Song, D.; Levin, L.; Meller, J.; Ho, S.M. Increased susceptibility of estrogen-induced bladder outlet obstruction in a novel mouse model. Lab. Investig. 2015, 95, 546-560. [CrossRef] [PubMed]

134. Shenfeld, O.Z.; McCammon, K.A.; Blackmore, P.F.; Ratz, P.H. Rapid effects of estrogen and progesterone on tone and spontaneous rhythmic contractions of the rabbit bladder. Urol. Res. 1999, 27, 386-392. [CrossRef] [PubMed]

135. Yasay, G.D.; Kau, S.T.; Li, J.H. Mechanoinhibitory effect of estradiol in guinea pig urinary bladder smooth muscles. Pharmacology 1995, 51, 273-280. [CrossRef]

136. Zhang, J.; Hess, M.W.; Thurnher, M.; Hobisch, A.; Radmayr, C.; Cronauer, M.V.; Hittmair, A.; Culig, Z.; Bartsch, G.; Klocker, H. Human prostatic smooth muscle cells in culture: Estradiol enhances expression of smooth muscle cell-specific markers. Prostate 1997, 30, 117-129. [CrossRef]

137. Scarano, W.R.; Cordeiro, R.S.; Goes, R.M.; Carvalho, H.F.; Taboga, S.R. Tissue remodeling in Guinea pig lateral prostate at different ages after estradiol treatment. Cell Biol. Int. 2005, 29, 778-784. [CrossRef]

138. Holterhus, P.M.; Zhao, G.Q.; Aumuller, G. Effects of androgen deprivation and estrogen treatment on the structure and protein expression of the rat coagulating gland. Anat. Rec. 1993, 235, 223-232. [CrossRef]

139. Tam, C.C.; Wong, Y.C. Ultrastructural study of the effects of 17 beta-oestradiol on the lateral prostate and seminal vesicle of the castrated guinea pig. Acta Anat. 1991, 141, 51-62.

140. Nicholson, T.M.; Nguyen, J.L.; Leverson, G.E.; Taylor, J.A.; Vom Saal, F.S.; Wood, R.W.; Ricke, W.A. Endocrine disruptor bisphenol A is implicated in urinary voiding dysfunction in male mice. Am. J. Physiol. Ren. Physiol. 2018, 315, F1208-F1216. [CrossRef]

141. Makowska, K.; Lech, P.; Majewski, M.; Rychlik, A.; Gonkowski, S. Bisphenol A affects vipergic nervous structures in the porcine urinary bladder trigone. Sci. Rep. 2021, 11, 12147. [CrossRef]

142. Bushman, W.A.; Jerde, T.J. The role of prostate inflammation and fibrosis in lower urinary tract symptoms. Am. J. Physiol. Ren. Physiol. 2016, 311, F817-F821. [CrossRef] [PubMed]

143. Lee, S.; Yang, G.; Bushman, W. Prostatic inflammation induces urinary frequency in adult mice. PLoS ONE 2015, 10, e0116827. [CrossRef] [PubMed]

144. Lloyd, G.L.; Ricke, W.A.; McVary, K.T. Inflammation, voiding and benign prostatic hyperplasia progression. J. Urol. 2019, 201, 868-870. [CrossRef] [PubMed]

145. Kaplan, S.A.; Roehrborn, C.G.; McConnell, J.D.; Meehan, A.G.; Surynawanshi, S.; Lee, J.Y.; Rotonda, J.; Kusek, J.W.; Nyberg, L.M., Jr. Long-term treatment with finasteride results in a clinically significant reduction in total prostate volume compared to placebo over the full range of baseline prostate sizes in men enrolled in the MTOPS trial. J. Urol. 2008, 180, 1030-1032. [CrossRef] [PubMed]

146. St Sauver, J.L.; Jacobson, D.J.; McGree, M.E.; Girman, C.J.; Lieber, M.M.; Jacobsen, S.J. Longitudinal association between prostatitis and development of benign prostatic hyperplasia. Urology 2008, 71, 475-479. [CrossRef]

147. Penna, G.; Fibbi, B.; Amuchastegui, S.; Cossetti, C.; Aquilano, F.; Laverny, G.; Gacci, M.; Crescioli, C.; Maggi, M.; Adorini, L. Human benign prostatic hyperplasia stromal cells as inducers and targets of chronic immuno-mediated inflammation. J. Immunol. 2009, 182, 4056-4064. [CrossRef]

148. Doiron, R.C.; Shoskes, D.A.; Nickel, J.C. Male cp/cpps: Where do we stand? World J. Urol. 2019, 37, 1015-1022. [CrossRef]

149. Roberts, R.O.; Lieber, M.M.; Bostwick, D.G.; Jacobsen, S.J. A review of clinical and pathological prostatitis syndromes. Urology 1997, 49, 809-821. [CrossRef] 
150. Cantiello, F.; Cicione, A.; Salonia, A.; Autorino, R.; Tucci, L.; Madeo, I.; Damiano, R. Periurethral fibrosis secondary to prostatic inflammation causing lower urinary tract symptoms: A prospective cohort study. Urology 2013, 81, 1018-1024. [CrossRef]

151. Macoska, J. Prostatic fibrosis is associated with lower urinary tract symptoms. J. Urol. 2012, 188, 1375-1381. [CrossRef]

152. Macoska, J.A.; Uchtmann, K.S.; Leverson, G.E.; McVary, K.T.; Ricke, W.A. Prostate transition zone fibrosis is associated with clinical progression in the MTOPS study. J. Urol. 2019, 202, 1240-1247. [CrossRef] [PubMed]

153. Ruetten, H.; Wegner, K.A.; Romero, M.F.; Wood, M.W.; Marker, P.C.; Strand, D.; Colopy, S.A.; Vezina, C.M. Prostatic collagen architecture in neutered and intact canines. Prostate 2018, 78, 839-848. [CrossRef] [PubMed]

154. Lee, S.; Yang, G.; Mulligan, W.; Gipp, J.; Bushman, W. Ventral prostate fibrosis in the Akita mouse is associated with macrophage and fibrocyte infiltration. J. Diabetes Res. 2014, 2014, 939053. [CrossRef] [PubMed]

155. Gharaee-Kermani, M.; Rodriguez-Nieves, J.A.; Mehra, R.; Vezina, C.A.; Sarma, A.V.; Macoska, J.A. Obesity-induced diabetes and lower urinary tract fibrosis promote urinary voiding dysfunction in a mouse model. Prostate 2013, 73, 1123-1133. [CrossRef]

156. Baumgarten, H.G.; Falck, B.; Holstein, A.F.; Owman, C.; Owman, T. Adrenergic innervation of the human testis, epididymis, ductus deferens and prostate: A fluorescence microscopic and fluorimetric study. Z. Zellforsch. Und Mikrosk. Anat. 1968, 90, 81-95. [CrossRef]

157. Caine, M.; Raz, S.; Zeigler, M. Adrenergic and cholinergic receptors in the human prostate, prostatic capsule and bladder neck. Br. J. Urol. 1975, 47, 193-202. [CrossRef]

158. Raz, S.; Zeigler, M.; Caine, M. Pharmacological receptors in the prostate. Br. J. Urol. 1973, 45, 663-667. [CrossRef]

159. Ricke, W.A.; Lee, C.W.; Clapper, T.R.; Schneider, A.J.; Moore, R.W.; Keil, K.P.; Abler, L.L.; Wynder, J.L.; Lopez Alvarado, A.; Beaubrun, I.; et al. In Utero and lactational TCDD exposure increases susceptibility to lower urinary tract dysfunction in adulthood. Toxicol. Sci. 2016, 150, 429-440. [CrossRef]

160. Turco, A.E.; Oakes, S.R.; Keil Stietz, K.P.; Dunham, C.L.; Joseph, D.B.; Chathurvedula, T.S.; Girardi, N.M.; Schneider, A.J.; Gawdzik, J.; Sheftel, C.M.; et al. A mechanism linking perinatal 2,3,7,8 tetrachlorodibenzo-p-dioxin exposure to lower urinary tract dysfunction in adulthood. Dis. Models Mech. 2021, 14, dmm049068. [CrossRef]

161. Gupta, A.; Ketchum, N.; Roehrborn, C.G.; Schecter, A.; Aragaki, C.C.; Michalek, J.E. Serum dioxin, testosterone, and subsequent risk of benign prostatic hyperplasia: A prospective cohort study of Air Force veterans. Environ. Health Perspect. 2006, 114, 1649-1654. [CrossRef]

162. Gupta, A.; Gupta, S.; Pavuk, M.; Roehrborn, C.G. Anthropometric and metabolic factors and risk of benign prostatic hyperplasia: A prospective cohort study of Air Force veterans. Urology 2006, 68, 1198-1205. [CrossRef]

163. Steers, W.D. Pathophysiology of overactive bladder and urge urinary incontinence. Rev. Urol. 2002, 4, S7. [PubMed]

164. De Nunzio, C.; Presicce, F.; Lombardo, R.; Carter, S.; Vicentini, C.; Tubaro, A. Detrusor overactivity increases bladder wall thickness in male patients: A urodynamic multicenter cohort study. Neurourol. Urodyn. 2017, 36, 1616-1621. [CrossRef] [PubMed]

165. Mumtaz, M.M.; Farooqui, M.Y.; Ghanayem, B.I.; Ahmed, A.E. The urotoxic effects of N,N'-dimethylaminopropionitrile. In vivo and in vitro metabolism. Toxicol. Appl. Pharmacol. 1991, 110, 61-69. [CrossRef]

166. Hara, N.; Saito, H.; Takahashi, K.; Takeda, M. Lower urinary tract symptoms in patients with Niigata Minamata disease: A case-control study 50 years after methyl mercury pollution. Int. J. Urol. 2013, 20, 610-615. [CrossRef]

167. Eto, K. Pathology of Minamata disease. Toxicol. Pathol. 1997, 25, 614-623. [CrossRef]

168. Smith, R.A.; Christenson, W.R.; Bartels, M.J.; Arnold, L.L.; St John, M.K.; Cano, M.; Garland, E.M.; Lake, S.G.; Wahle, B.S.; McNett, D.A.; et al. Urinary physiologic and chemical metabolic effects on the urothelial cytotoxicity and potential DNA adducts of o-phenylphenol in male rats. Toxicol. Appl. Pharmacol. 1998, 150, 402-413. [CrossRef]

169. Abrams, P.; Cardozo, L.; Fall, M.; Griffiths, D.; Rosier, P.; Ulmsten, U.; Van Kerrebroeck, P.; Victor, A.; Wein, A. The standardisation of terminology of lower urinary tract function: Report from the Standardisation Sub-committee of the International Continence Society. Am. J. Obstet. Gynecol. 2002, 187, 116-126. [CrossRef]

170. Miyazato, M.; Yoshimura, N.; Chancellor, M.B. The other bladder syndrome: Underactive bladder. Rev. Urol. 2013, 15, 11-22.

171. Kim, S.J.; Kim, J.; Na, Y.G.; Kim, K.H. Irreversible bladder remodeling induced by fibrosis. Int. Neurourol. J. 2021, 25 , S3-S7. [CrossRef]

172. Feng, J.; Gao, J.; Zhou, S.; Liu, Y.; Zhong, Y.; Shu, Y.; Meng, M.S.; Yan, J.; Sun, D.; Fang, Q.; et al. Role of stem cell factor in the regulation of ICC proliferation and detrusor contraction in rats with an underactive bladder. Mol. Med. Rep. 2017, 16, 1516-1522. [CrossRef] [PubMed]

173. Castro-Diaz, D.; Taracena Lafuente, J.M. Detrusor-sphincter dyssynergia. Int. J. Clin. Pract. Suppl. 2006, 151, 17-21. [CrossRef]

174. Stoffel, J.T. Detrusor sphincter dyssynergia: A review of physiology, diagnosis, and treatment strategies. Transl. Androl. Urol. 2016, 5, 127-135. [PubMed]

175. Amarenco, G.; Sheikh Ismaël, S.; Chesnel, C.; Charlanes, A.; Le Breton, F. Diagnosis and clinical evaluation of neurogenic bladder. Eur. J. Phys. Rehabil. Med. 2017, 53, 975-980. [CrossRef] [PubMed]

176. Ito, H.; Yoshiyasu, T.; Yamaguchi, O.; Yokoyama, O. Male lower urinary tract symptoms: Hypertension as a risk factor for storage symptoms, but not voiding symptoms. Lower Urin. Tract Symptoms 2012, 4, 68-72. [CrossRef]

177. Wang, X.; Su, Y.; Yang, C.; Hu, Y.; Dong, J.-Y. Benign prostatic hyperplasia and cardiovascular risk: A prospective study among chinese men. World J. Urol. 2021, 40,177-183. [CrossRef]

178. Hammarsten, J.; Högstedt, B. Clinical, anthropometric, metabolic and insulin profile of men with fast annual growth rates of benign prostatic hyperplasia. Blood Press. 1999, 8, 29-36. 
179. Abler, L.L.; Vezina, C.M. Links between lower urinary tract symptoms, intermittent hypoxia and diabetes: Causes or cures? Respir. Physiol. Neurobiol. 2018, 256, 87-96. [CrossRef]

180. Lejay, A.; Fang, F.; John, R.; Van, J.A.D.; Barr, M.; Thaveau, F.; Chakfe, N.; Geny, B.; Scholey, J.W. Ischemia reperfusion injury, ischemic conditioning and diabetes mellitus. J. Mol. Cell. Cardiol. 2016, 91, 11-22. [CrossRef]

181. Vinik, A.I.; Maser, R.E.; Mitchell, B.D.; Freeman, R. Diabetic autonomic neuropathy. Diabetes Care 2003, 26, 1553-1579. [CrossRef]

182. Morgan, B.J. Vascular consequences of intermittent hypoxia. In Hypoxia and the Circulation; Springer: Berlin/Heidelberg, Germany, 2007; pp. 69-84.

183. Andersson, K.E.; Boedtkjer, D.B.; Forman, A. The link between vascular dysfunction, bladder ischemia, and aging bladder dysfunction. Ther. Adv. Urol. 2017, 9, 11-27. [CrossRef] [PubMed]

184. Lind, L.; Lind, P.M. Can persistent organic pollutants and plastic-associated chemicals cause cardiovascular disease? J. Int. Med. 2012, 271, 537-553. [CrossRef]

185. Meneguzzi, A.; Fava, C.; Castelli, M.; Minuz, P. Exposure to perfluoroalkyl chemicals and cardiovascular disease: Experimental and epidemiological evidence. Front. Endocrinol. 2021, 12, 850. [CrossRef] [PubMed]

186. Velmurugan, G.; Ramprasath, T.; Gilles, M.; Swaminathan, K.; Ramasamy, S. Gut microbiota, endocrine-disrupting chemicals, and the diabetes epidemic. Trends Endocrinol. Metab. 2017, 28, 612-625. [CrossRef] [PubMed]

187. Muller, W.J.; Lee, F.S.; Dickson, C.; Peters, G.; Pattengale, P.; Leder, P. The int-2 gene product acts as an epithelial growth factor in transgenic mice. EMBO J. 1990, 9, 907-913. [CrossRef]

188. Konno-Takahashi, N.; Takeuchi, T.; Nishimatsu, H.; Kamijo, T.; Tomita, K.; Schalken, J.A.; Teshima, S.; Kitamura, T. Engineered FGF-2 expression induces glandular epithelial hyperplasia in the murine prostatic dorsal lobe. Eur. Urol. 2004, 46, 126-132. [CrossRef]

189. Tutrone, R.F., Jr.; Ball, R.A.; Ornitz, D.M.; Leder, P.; Richie, J.P. Benign prostatic hyperplasia in a transgenic mouse: A new hormonally sensitive investigatory model. J. Urol. 1993, 149, 633-639. [CrossRef]

190. Wennbo, H.; Kindblom, J.; Isaksson, O.G.; Törnell, J. Transgenic mice overexpressing the prolactin gene develop dramatic enlargement of the prostate gland. Endocrinology 1997, 138, 4410-4415. [CrossRef]

191. Pigat, N.; Reyes-Gomez, E.; Boutillon, F.; Palea, S.; Barry Delongchamps, N.; Koch, E.; Goffin, V. Combined sabal and urtica extracts (WS((R)) 1541) exert anti-proliferative and anti-inflammatory effects in a mouse model of benign prostate hyperplasia. Front. Pharmacol. 2019, 10, 311. [CrossRef]

192. Bernichtein, S.; Pigat, N.; Camparo, P.; Latil, A.; Viltard, M.; Friedlander, G.; Goffin, V. Anti-inflammatory properties of lipidosterolic extract of serenoa repens (Permixon(R)) in a mouse model of prostate hyperplasia. Prostate 2015, 75, 706-722. [CrossRef]

193. Dillner, K.; Kindblom, J.; Flores-Morales, A.; Pang, S.T.; Tornell, J.; Wennbo, H.; Norstedt, G. Molecular characterization of prostate hyperplasia in prolactin-transgenic mice by using cDNA representational difference analysis. Prostate 2002, 52, 139-149. [CrossRef] [PubMed]

194. Vital, P.; Castro, P.; Tsang, S.; Ittmann, M. The senescence-associated secretory phenotype promotes benign prostatic hyperplasia. Am. J. Pathol. 2014, 184, 721-731. [CrossRef] [PubMed]

195. George, J.W.; Patterson, A.L.; Tanwar, P.S.; Kajdacsy-Balla, A.; Prins, G.S.; Teixeira, J.M. Specific deletion of LKB1/Stk11 in the Mullerian duct mesenchyme drives hyperplasia of the periurethral stroma and tumorigenesis in male mice. Proc. Natl. Acad. Sci. USA 2017, 114, 3445-3450. [CrossRef] [PubMed]

196. Wegner, K.A.; Mueller, B.R.; Unterberger, C.J.; Avila, E.J.; Ruetten, H.; Turco, A.E.; Oakes, S.R.; Girardi, N.M.; Halberg, R.B.; Swanson, S.M.; et al. Prostate epithelial-specific expression of activated PI3K drives stromal collagen production and accumulation. J. Pathol. 2020, 250, 231-242. [CrossRef]

197. Turkbey, B.; Huang, R.; Vourganti, S.; Trivedi, H.; Bernardo, M.; Yan, P.; Benjamin, C.; Pinto, P.A.; Choyke, P.L. Age-related changes in prostate zonal volumes as measured by high-resolution magnetic resonance imaging (MRI): A cross-sectional study in over 500 patients. BJU Int. 2012, 110, 1642-1647. [CrossRef]

198. Nickel, J.C.; Roehrborn, C.G.; O'Leary, M.P.; Bostwick, D.G.; Somerville, M.C.; Rittmaster, R.S. The relationship between prostate inflammation and lower urinary tract symptoms: Examination of baseline data from the REDUCE trial. Eur. Urol. 2008, 54, 1379-1384. [CrossRef]

199. Nickel, J.C. Prostatitis. Can. Urol. Assoc. J. 2011, 5, 306-315. [CrossRef]

200. Aiello, S.E.; Moses, M.A.; Allen, D.G. The Merck Veterinary Manual, 11th ed.; Merck \& Co. Inc.: Kenilworth, NJ, USA, $2016 ;$ p. 3325.

201. Krieger, J.N.; Riley, D.E. Bacteria in the chronic prostatitis-chronic pelvic pain syndrome: Molecular approaches to critical research questions. J. Urol. 2002, 167, 2574-2583. [CrossRef]

202. Elkahwaji, J.E.; Ott, C.J.; Janda, L.M.; Hopkins, W.J. Mouse model for acute bacterial prostatitis in genetically distinct inbred strains. Urology 2005, 66, 883-887. [CrossRef]

203. Rudick, C.N.; Berry, R.E.; Johnson, J.R.; Johnston, B.; Klumpp, D.J.; Schaeffer, A.J.; Thumbikat, P. Uropathogenic Escherichia coli induces chronic pelvic pain. Infect. Immun. 2011, 79, 628-635. [CrossRef]

204. Nowicki, B.; Singhal, J.; Fang, L.; Nowicki, S.; Yallampalli, C. Inverse relationship between severity of experimental pyelonephritis and nitric oxide production in $\mathrm{C} 3 \mathrm{H} / \mathrm{HeJ}$ mice. Infect. Immun. 1999, 67, 2421-2427. [CrossRef] [PubMed] 
205. Ruetten, H.; Sandhu, J.; Mueller, B.; Wang, P.; Zhang, H.L.; Wegner, K.A.; Cadena, M.; Sandhu, S.; Abler, L.L.; Zhu, J.; et al. A uropathogenic E. coli UTI89 model of prostatic inflammation and collagen accumulation for use in studying aberrant collagen production in the prostate. Am. J. Physiol. Ren. Physiol. 2021, 320, F31-F46. [CrossRef] [PubMed]

206. Bell-Cohn, A.; Mazur, D.J.; Hall, C.C.; Schaeffer, A.J.; Thumbikat, P. Uropathogenic Escherichia coli-induced fibrosis, leading to lower urinary tract symptoms, is associated with type-2 cytokine signaling. Am. J. Physiol. Ren. Physiol. 2019, 316, F682-F692 [CrossRef]

207. Wang, H.H.; Wang, L.; Jerde, T.J.; Chan, B.D.; Savran, C.A.; Burcham, G.N.; Crist, S.; Ratliff, T.L. Characterization of autoimmune inflammation induced prostate stem cell expansion. Prostate 2015, 75, 1620-1631. [CrossRef] [PubMed]

208. Motrich, R.D.; Maccioni, M.; Molina, R.; Tissera, A.; Olmedo, J.; Riera, C.M.; Rivero, V.E. Presence of INFgamma-secreting lymphocytes specific to prostate antigens in a group of chronic prostatitis patients. Clin. Immunol. 2005, 116, 149-157. [CrossRef]

209. Habermacher, G.M.; Chason, J.T.; Schaeffer, A.J. Prostatitis/chronic pelvic pain syndrome. Annu. Rev. Med. 2006, 57, 195-206. [CrossRef]

210. Lees, J.R.; Charbonneau, B.; Hayball, J.D.; Diener, K.; Brown, M.; Matusik, R.; Cohen, M.B.; Ratliff, T.L. T-cell recognition of a prostate specific antigen is not sufficient to induce prostate tissue destruction. Prostate 2006, 66, 578-590. [CrossRef]

211. Lees, J.R.; Charbonneau, B.; Swanson, A.K.; Jensen, R.; Zhang, J.; Matusik, R.; Ratliff, T.L. Deletion is neither sufficient nor necessary for the induction of peripheral tolerance in mature CD8+ T cells. Immunology 2006, 117, 248-261. [CrossRef]

212. Done, J.D.; Rudick, C.N.; Quick, M.L.; Schaeffer, A.J.; Thumbikat, P. Role of mast cells in male chronic pelvic pain. J. Urol. 2012, 187, 1473-1482. [CrossRef]

213. Rudick, C.N.; Schaeffer, A.J.; Thumbikat, P. Experimental autoimmune prostatitis induces chronic pelvic pain. Am. J. Physiol. Regul. Integr. Comp. Physiol. 2008, 294, R1268-R1275. [CrossRef]

214. Lang, M.D.; Nickel, J.C.; Olson, M.E.; Howard, S.R.; Ceri, H. Rat model of experimentally induced abacterial prostatitis. Prostate 2000, 45, 201-206. [CrossRef]

215. Funahashi, Y.; O’Malley, K.J.; Kawamorita, N.; Tyagi, P.; DeFranco, D.B.; Takahashi, R.; Gotoh, M.; Wang, Z.; Yoshimura, N. Upregulation of androgen-responsive genes and transforming growth factor- $\beta 1$ cascade genes in a rat model of non-bacterial prostatic inflammation. Prostate 2014, 74, 337-345. [CrossRef] [PubMed]

216. Mizoguchi, S.; Mori, K.; Wang, Z.; Liu, T.; Funahashi, Y.; Sato, F.; DeFranco, D.B.; Yoshimura, N.; Mimata, H. Effects of estrogen receptor $\beta$ stimulation in a rat model of non-bacterial prostatic inflammation. Prostate 2017, 77, 803-811. [CrossRef] [PubMed]

217. Funahashi, Y.; Wang, Z.; O’Malley, K.J.; Tyagi, P.; DeFranco, D.B.; Gingrich, J.R.; Takahashi, R.; Majima, T.; Gotoh, M.; Yoshimura, N Influence of $E$. coli-induced prostatic inflammation on expression of androgen-responsive genes and transforming growth factor beta 1 cascade genes in rats. Prostate 2015, 75, 381-389. [CrossRef]

218. Torkko, K.C.; Wilson, R.S.; Smith, E.E.; Kusek, J.W.; van Bokhoven, A.; Lucia, M.S. Prostate biopsy markers of inflammation are associated with risk of clinical progression of benign prostatic hyperplasia: Finding for the MTOPS study. J. Urol. 2015, 194, 454-461. [CrossRef]

219. Pontari, M.A.; Ruggieri, M.R. Mechanisms in prostatitis/chronic pelvic pain syndrome. J. Urol. 2004, 172, 839-845. [CrossRef]

220. Nadler, R.B.; Koch, A.E.; Calhoun, E.A.; Campbell, P.L.; Pruden, D.L.; Bennett, C.L.; Yarnold, P.R.; Schaeffer, A.J. IL-1beta and TNF-alpha in prostatic secretions are indicators in the evaluation of men with chronic prostatitis. J. Urol. 2000, 164, 214-218. [CrossRef]

221. Huang, T.R.; Li, W.; Peng, B. Correlation of inflammatory mediators in prostatic secretion with chronic prostatitis and chronic pelvic pain syndrome. Andrologia 2018, 50, e12860. [CrossRef]

222. Ricote, M.; García-Tuñón, I.; Bethencourt, F.R.; Fraile, B.; Paniagua, R.; Royuela, M. Interleukin-1 (IL-1alpha and IL-1beta) and its receptors (IL-1RI, IL-1RII, and IL-1Ra) in prostate carcinoma. Cancer 2004, 100, 1388-1396. [CrossRef]

223. Ashok, A.; Keener, R.; Rubenstein, M.; Stookey, S.; Bajpai, S.; Hicks, J.; Alme, A.K.; Drake, C.G.; Zheng, Q.; Trabzonlu, L.; et al. Consequences of interleukin $1 \beta$-triggered chronic inflammation in the mouse prostate gland: Altered architecture associated with prolonged CD4(+) infiltration mimics human proliferative inflammatory atrophy. Prostate 2019, 79, 732-745. [CrossRef]

224. Hao, L.; Thomas, S.; Greer, T.; Vezina, C.M.; Bajpai, S.; Ashok, A.; De Marzo, A.M.; Bieberich, C.J.; Li, L.; Ricke, W.A. Quantitative proteomic analysis of a genetically induced prostate inflammation mouse model via custom 4-plex DiLeu isobaric labeling. Am. J. Physiol. Ren. Physiol. 2019, 316, F1236-F1243. [CrossRef]

225. Hao, L.; Shi, Y.; Thomas, S.; Vezina, C.M.; Bajpai, S.; Ashok, A.; Bieberich, C.J.; Ricke, W.A.; Li, L. Comprehensive urinary metabolomic characterization of a genetically induced mouse model of prostatic inflammation. Int. J. Mass Spectrom. 2018, 434, 185-192. [CrossRef] [PubMed]

226. O’Malley, K.J.; Eisermann, K.; Pascal, L.E.; Parwani, A.V.; Majima, T.; Graham, L.; Hrebinko, K.; Acquafondata, M.; Stewart, N.A.; Nelson, J.B.; et al. Proteomic analysis of patient tissue reveals PSA protein in the stroma of benign prostatic hyperplasia. Prostate 2014, 74, 892-900. [CrossRef] [PubMed]

227. Pascal, L.E.; Mizoguchi, S.; Chen, W.; Rigatti, L.H.; Igarashi, T.; Dhir, R.; Tyagi, P.; Wu, Z.; Yang, Z.; de Groat, W.C.; et al. Prostatespecific deletion of cdh1 induces murine prostatic inflammation and bladder overactivity. Endocrinology 2021, 162, bqaa212 [CrossRef]

228. Eljamal, K.; Kajioka, S.; Maki, T.; Ushijima, M.; Kawagoe, K.; Lee, K.; Sasaguri, T. New mouse model of underactive bladder developed by placement of a metal ring around the bladder neck. Lower Urin. Tract Symptoms 2021, 13, 299-307. [CrossRef] [PubMed] 
229. Austin, J.C.; Chacko, S.K.; DiSanto, M.; Canning, D.A.; Zderic, S.A. A male murine model of partial bladder outlet obstruction reveals changes in detrusor morphology, contractility and Myosin isoform expression. J. Urol. 2004, 172, 1524-1528. [CrossRef]

230. Taylor, J.A.; Zhu, Q.; Irwin, B.; Maghaydah, Y.; Tsimikas, J.; Pilbeam, C.; Leng, L.; Bucala, R.; Kuchel, G.A. Null mutation in macrophage migration inhibitory factor prevents muscle cell loss and fibrosis in partial bladder outlet obstruction. Am. J. Physiol. Ren. Physiol. 2006, 291, F1343-F1353. [CrossRef]

231. Chen, J.; Drzewiecki, B.A.; Merryman, W.D.; Pope, J.C. Murine bladder wall biomechanics following partial bladder obstruction. J. Biomechem. 2013, 46, 2752-2755. [CrossRef]

232. Vasquez, E.; Cristofaro, V.; Lukianov, S.; Burkhard, F.C.; Gheinani, A.H.; Monastyrskaya, K.; Bielenberg, D.R.; Sullivan, M.P.; Adam, R.M. Deletion of neuropilin 2 enhances detrusor contractility following bladder outlet obstruction. JCI Insight 2017, 2, e90617. [CrossRef]

233. Streng, T.; Li, X.; Lehtoranta, M.; Makela, S.; Poutanen, M.; Talo, A.; Tekmal, R.R.; Santti, R. Infravesical obstruction in aromatase over expressing transgenic male mice with increased ratio of serum estrogen-to-androgen concentration. J. Urol. 2002, 168, 298-302. [CrossRef]

234. Wegner, K.A.; Ruetten, H.; Girardi, N.M.; O’Driscoll, C.A.; Sandhu, J.K.; Turco, A.E.; Abler, L.L.; Wang, P.; Wang, Z.; Bjorling, D.E.; et al. Genetic background but not prostatic epithelial beta-catenin influences susceptibility of male mice to testosterone and estradiol-induced urinary dysfunction. Am. J. Clin. Exp. Urol. 2021, 9, 121-131.

235. Konkol, Y.; Vuorikoski, H.; Streng, T.; Tuomela, J.; Bernoulli, J. Characterization a model of prostatic diseases and obstructive voiding induced by sex hormone imbalance in the Wistar and Noble rats. Transl. Androl. Urol. 2019, 8, S45-S57. [CrossRef] [PubMed]

236. Gopal, M.; Sammel, M.D.; Arya, L.A.; Freeman, E.W.; Lin, H.; Gracia, C. Association of change in estradiol to lower urinary tract symptoms during the menopausal transition. Obstet. Gynecol. 2008, 112, 1045-1052. [CrossRef]

237. Nicholson, T.M.; Moses, M.A.; Uchtmann, K.S.; Keil, K.P.; Bjorling, D.E.; Vezina, C.M.; Wood, R.W.; Ricke, W.A. Estrogen receptor-alpha is a key mediator and therapeutic target for bladder complications of benign prostatic hyperplasia. J. Urol. 2015, 193, 722-729. [CrossRef] [PubMed]

238. Buhl, A.E.; Yuan, Y.D.; Cornette, J.C.; Frielink, R.D.; Knight, K.A.; Ruppel, P.L.; Kimball, F.A. Steroid-induced urogenital tract changes and urine retention in laboratory rodents. J. Urol. 1985, 134, 1262-1267. [CrossRef]

239. Collins, D.E.; Mulka, K.R.; Hoenerhoff, M.J.; Taichman, R.S.; Villano, J.S. Clinical assessment of urinary tract damage during sustained-release estrogen supplementation in mice. Comp. Med. 2017, 67, 11-21. [PubMed]

240. Van Steenbrugge, G.J.; Groen, M.; de Jong, F.H.; Schroeder, F.H. The use of steroid-containing silastic implants in male nude mice: Plasma hormone levels and the effect of implantation on the weights of the ventral prostate and seminal vesicles. Prostate 1984, 5, 639-647. [CrossRef]

241. Nomiya, M.; Yamaguchi, O.; Andersson, K.-E.; Sagawa, K.; Aikawa, K.; Shishido, K.; Yanagida, T.; Kushida, N.; Yazaki, J.; Takahashi, N. The effect of atherosclerosis-induced chronic bladder ischemia on bladder function in the rat. Neurourol. Urodyn. 2012, 31, 195-200. [CrossRef]

242. Yoshida, A.; Kageyama, A.; Fujino, T.; Nozawa, Y.; Yamada, S. Loss of muscarinic and purinergic receptors in urinary bladder of rats with hydrochloric acid-induced cystitis. Urology 2010, 76, 1017-e7. [CrossRef]

243. Kakizaki, H.; de Groat William, C. Role of spinal nitric oxide in the facilitation of the micturition reflex by bladder irritation. $J$. Urol. 1996, 155, 355-360. [CrossRef]

244. Mitsui, T.; Kakizaki, H.; Matsuura, S.; Ameda, K.; Yoshioka, M.; Koyanagi, T. Afferent fibers of the hypogastric nerves are involved in the facilitating effects of chemical bladder irritation in rats. J. Neurophysiol. 2001, 86, 2276-2284. [CrossRef] [PubMed]

245. Tai, C.; Shen, B.; Chen, M.; Wang, J.; Liu, H.; Roppolo, J.R.; de Groat, W.C. Suppression of bladder overactivity by activation of somatic afferent nerves in the foot. BJU Int. 2011, 107, 303. [CrossRef] [PubMed]

246. Choudhary, M.; van Asselt, E.; van Mastrigt, R.; Clavica, F. Neurophysiological modeling of bladder afferent activity in the rat overactive bladder model. J. Physiol. Sci. 2015, 65, 329-338. [CrossRef] [PubMed]

247. Wang, Z.; Liao, L. Improvement in detrusor-sphincter dyssynergia by bladder-wall injection of replication-defective herpes simplex virus vector-mediated gene delivery of kynurenine aminotransferase II in spinal cord injury rats. Spinal Cord 2017, 55, 155-161. [CrossRef]

248. Saito, T.; Gotoh, D.; Wada, N.; Tyagi, P.; Minagawa, T.; Ogawa, T.; Ishizuka, O.; Yoshimura, N. Time-dependent progression of neurogenic lower urinary tract dysfunction after spinal cord injury in the mouse model. Am. J. Physiol. Ren. Physiol. 2021, 321, F26-F32. [CrossRef] 